\title{
REVIEW
}

\section{Coral Populations on Reef Slopes and Their Major Controls}

\author{
C. R. C. Sheppard \\ Australian Institute of Marine Science, P.M.B. No. 3, Townsville M.S.O., Q. 4810, Australia
}

\begin{abstract}
Ecological studies of corals on reef slopes published in the last 10-15 y are reviewed. Emphasis is placed on controls of coral distributions. Reef slope structures are defined with particular reference to the role of corals in providing constructional framework. General coral distributions are synthesized from widespread reefs and are described in the order: shallowest, most exposed reef slopes; main region of hermatypic growth; deepest studies conducted by SCUBA or submersible, and cryptic habitats. Most research has concerned the area between the shallow and deep extremes. Favoured methods of study have involved cover, zonation and diversity, although inadequacies of these simple measurements have led to a few multivariate treatments of data. The importance of early life history strategies and their influence on succession and final community structure is emphasised. Control of coral distribution exerted by their dual nutrition requirements - particulate food and light are the least understood despite being extensively studjed. Well studied controls include water movement, sedimentation and predation. All influence coral populations directly and by acting on competitors. Finally, controls on coral population structure by competitive processes between species, and between corals and other taxa are illustrated. Their importance to general reef ecology so far as currently is known, is described
\end{abstract}

\section{INTRODUCTION}

Twelve years ago, Wells (1969) wrote: 'In the IndoPacific our present knowledge of the reef coral populations is based almost wholly on the easily reached shallow water habitats. Only scattered handfuls of specimens have been recovered from depths of more than a few metres.' Since then, coral reef research has been extended considerably from the reef flat and other shallow areas to reef slopes. Widespread use of SCUBA has permitted detailed scientific exploration of the slope beyond the breaking waves, and has led to the realization of the important contribution of the reef slope to the growth and maintenance of the entire reef system. The diversity and complexity of the coral communities of this area generally considerably exceed those of the reef flats and shallows, and the region has proved to be a fertile testing ground for ecological ideas as well as for descriptive work. Continuing work has extended the known depths at which corals and algae can thrive. The literature now contains several ecological studies of reef corals beyond $50 \mathrm{~m}$ to as deep as $100 \mathrm{~m}$

This single order of coelenterates forms to a large extent the foundation of the reef, and thus its own substrate and environment. While not alone in this, corals are probably the most significant; this is reflected in the volume of work devoted to them. Information on coral ecology of reef slopes is now available from a number of localities in both the Atlantic and Indo-Pacific coral provinces. Much of it is relatively brief work, such as short term investigations of more remote areas. Very detailed work, however, has appeared from an increasing number of areas; notable amongst these are Jamaica and Curaçao in the Atlantic region, Eilat and Madagascar from the Red Sea and Indian Ocean, centres on the Great Barrier Reef, Hawaii, and several others. Early coral ecology was reviewed by Stoddart (1969) which, while concerned largely with shallow areas, included existing information on the reef slope.

Most work considered here was done in the late 
1960 's and 1970's and primarily concerns the reef slope. Some notable earlier investigations, e.g. of Goreau, (1959a), stimulated much of this research. Work on shallow areas is included where this is relevant to, or forms a continuation of, deeper or reef slope work.

The subject matter is divided into 3 categories: (1) types, aspects and coral framework of reef slopes in general; (2) general distributions of corals between the upper limits of the reef slope to $100 \mathrm{~m}$; (3) physical and biological controls of coral distribution, including that due to competition between species. Throughout descriptive studies are collated into generalized patterns. Where possible, emphasis is placed on the mechanisms by which environmental and biological effects influence coral populations. Also, the problem of the relative importance of each major control in various situations is addressed.

\section{REEF SLOPE STRUCTURE AND CORAL FRAMEWORK}

\section{Structure}

The area of reef under review varies in morphology, origin and complexity, and in the names applied to it. 'Reef slope' here means all areas except reef flats or other parts which dry or show ponding at low water. The upper limit is commonly the low water mark, algal ridge or other reef crest structure. In some circumstances the shallowest point may begin deeper, such as with lagoon knolls. The lower limit here is the deepest extent of hermatypic corals.

Terms used for often essentially similar areas are unnecessarily profuse. They include 'outer wall', 'fore reef' (Stoddart, 1973), 'outer slope' (Davies et al., 1971; Pichon, 1971, 1978), 'reef front' (Barnes et al., 1971), 'fore reef' or 'fore reef slope' (Loya and Slobodkin, 1971; Goreau and Goreau, 1973), 'off reef' (Ladd, 1977), 'outward slope' (Mergner, 1971), 'coral flagstone' (Pichon, 1978), '4.5 fathom terrace, 10 fathom terrace, deep reef slope' (Dana, 1979), and several others. The term 'reef slope' is frequently used in ways corresponding to all of the above, commonly with an adjective (seaward, deep, etc.). It is here taken as a generic term for this region.

Where 2 or more terms subdivide the slope, e.g. Dana (1979) above, they usually denote a sudden change of gradient due to a 'drop off', to shelving, or to a change of substrate. More widespread is the use of zones named after the dominant coral species to denote a particular section of reef slope; these are sometimes confused with morphologically based descriptions. Most reef slopes have appreciable gradients but few are smoothly continuous, being compli- cated by a variety of structures such as buttresses and caves commonly resulting from past lowered sea levels or from recent irregular growth.

Most barrier reefs and atolls, but not necessarily fringing reefs, have reef slopes whose total area is less than that of the reef flat by several orders of magnitude. Plan views of most reefs necessarily exclude the reef slope altogether. Reef terminology summarised by Stoddart (1978) even omits mention of this region. Although small in width - they may extend only $50 \mathrm{~m}$ from shallowest to deepest points - their length may be many kilometers. They thus exhibit environmental gradients associated with increasing depth and changing exposure, providing an ideal ground for determining the controls of coral distribution. By many ecological measures they include the richest coral communities of all (later sections).

Schematic examples of 6 well-studied reef slopes show their main topographic features (Fig. 1). Some variety is evident, with most differences evident at their shallow end. Since corals to a great extent form their own substrate, some feedback exists between the coral ecology and slope morphology. For example, chutes in Jamaica are self-perpetuating to some degree (Goreau and Goreau, 1973) while the steep angles characteristic of many reef slopes are sometimes regarded as indicative of active growth. Nevertheless, in many cases reef morphology is strongly influenced by underlying topography of ancient or non-limestone origin (e.g. Goreau and Burke, 1966; Goreau, 1969). Where coral communities only veneer such structures, distriction has been drawn between structural reefs and coral communities (Goreau, 1969; Stoddart, 1969). This is probably important to present coral ecology. Eustatic sea level changes suggest that reefs shallower than about $25 \mathrm{~m}$ are relatively young, younger than some of man's earlier civilizations (Goreau, 1969). Given the longevity and slow growth rate of corals, Goreau argued that this brief span was insufficient to damp out initial randomness in coral growth and framework building - this being a cause of many present reef and community discontinuities.

Generally, atolls are formed of limestone to depths of up to several kilometers and have steep slopes to seaward but more complex slopes lagoonward. Reefs close to or influenced by land (e.g. barrier, fringing or patch reefs), may have slopes more strongly influenced by a wider variety of terrigenous influences such as rivers, sediment, and topographical complexities. They may be less steep and hence more extensive, but many extend to only moderate depth before reaching a horizontal, soft sea floor. Other than these generalizations, however, it is not possible to categorise reef slope types in the same manner as for whole reef structures. 

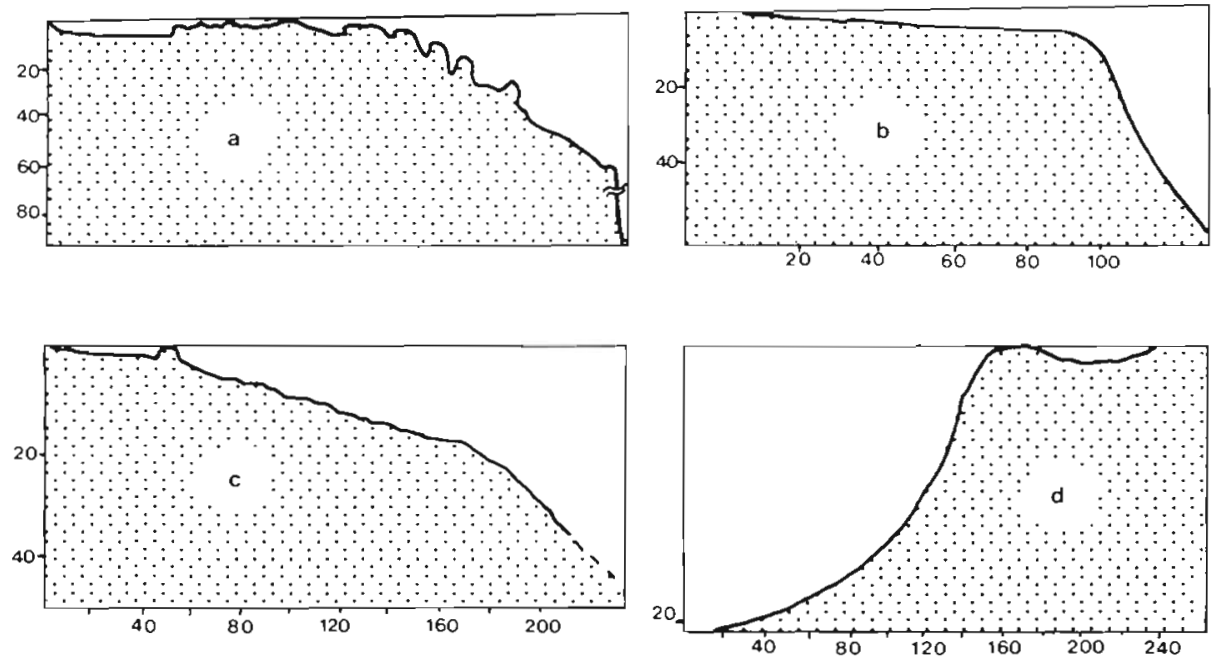

1. Reef slope profiles from reefs assumed to be accreting, showing main inclinations and additional features when present. All numbers are distances or depths in $m$. (a) Discovery Bay, Jamaica (Goreau and Goreau, 1973); (b) Curaçao, Netherlands Antilles (Van den Hoek et al., 1978); (c) Eilat, Red Sea (Loya and Slobodkin, 1971); (d) Tuléar, Madagascar (Pichon, 1978); (e) Chagos, Indian Ocean (Sheppard, 1981a); (f) McKean, Phoenix Is. (Dana, 1979)
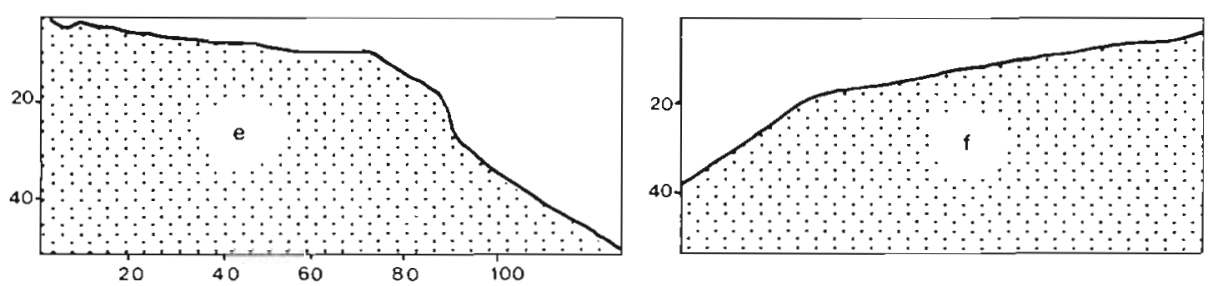

\section{Coral Framework}

A fundamental, non-taxonomic division of Scleractinia divides genera about equally into 2 groups: those containing or lacking symbiotic zooxanthellae. The latter show the widest distribution, but those which appropriated algae became able to diversify considerably and attain a wider range of colony shape and size (Wells, 1956; Yonge, 1973). These include species of reef building importance

Amongst corals it is common to equate reef building or hermatypic with zooxanthellae-containing, and ahermatypic or non-reef building with asymbiotic corals. This can be misleading. For example, Goreau and Yonge (1968) found symbiotic but non-reef building dendrophylliids and fungiids, while Sheppard (1981a) lists 5 asymbiotic genera in Chagos with reef building roles considerably greater than the 5 least frequent symbiotic genera. Oculina develops reefs in deep water off Florida (Reed, 1980), while Land and Moore (1977) suggest the asymbiotic Desmophyllum provides a 'superficial framework' at $200 \mathrm{~m}$ in Jamaica. At similar depths in cooler seas Lophelia patches may be considerable (Wilson, 1979). Many families contain genera of both groups; very few genera (e. g. Madracis) contain species in both, and Astrangia danae exists in either form (Jaques and Pilson, 1980). Some asymbiotic species may contain zooxanthellae in nutritionally insignificant amounts (Goreau et al., 1979), and several symbiotic corals lose their zooxanthellae, surviving aposymbiotically for extended periods (Jaap, 1979).

Despite such exceptions or oddities, only symbiotic corals are generally regarded as hermatypic. The reason is the enhanced vigour and calcification embued to the former by the algae, a phenomenon documented by the Goreaus (Goreau, 1959b, 1961a, b, 1963; Goreau and Goreau, 1959, 1960a, b) and later authors (e.g. Pearse and Muscatine, 1971; Chalker and Taylor, 1975, 1978; Chalker, 1976, 1977; Johnston, 1977). The greater fitness provided by the association in warm illuminated areas has largely excluded asymbiotic species from the coral reef, though some species may also be photophobic (Wells, 1973).

The concept of framework species, introduced by Goreau (1959a) and later amplified into primary and secondary types (Goreau and Goreau, 1973) has proved to be widely illustrative. Primary framework species provide, literally, a frame in and around which subsequent flora and fauna, including corals, may grow. Secondary hermatypes (Goreau and Goreau, 1973) may then produce most $\mathrm{CaCO}_{3}$, as intact, small colonies or as sediment; or they may be important for binding and stabilizing the substrate. They include encrusting algae (Dahl, 1974) and sponges (Wulff and Buss, 1979) as well as corals. Schroeder and Zankl (1974) proposed a concept of dynamic reef growth. This begins with primary framework builders. Secondary framework species follow which are initially smaller in 
Table 1 Species cited or inferred as main framework builders

\begin{tabular}{|c|c|c|}
\hline Species & Site (depth, m) & Source \\
\hline \multicolumn{3}{|l|}{ Allantic Ocean } \\
\hline \multirow[t]{4}{*}{ Acropora palmata } & Jamaica $(0-6)$ & Goreau (1959a) \\
\hline & Florida $(0-3)$ & Shinn (1963) \\
\hline & Bonaire & Scatterday (1974) \\
\hline & Lesser Antilles $(0-10)$ & Adey \& Burke (1977) \\
\hline A. cervicornis & Bonaire & Scatterday (1974); Tunnicliffe (1981) \\
\hline Porites furcata & Panama $(0-2.5)$ & Glynn $(1973 a, c)$ \\
\hline \multirow[t]{3}{*}{ Montastrea annularis } & Jamaica $(6-20+)$ & Goreau (1959a) \\
\hline & Lesser Antilles $(6+)$ & Adey \& Burke (1977) \\
\hline & Bonaire & Scatterday (1974) \\
\hline M. cavernosa & Puerto Rico $(8-20)$ & Loya (1976a) \\
\hline Millepora spp. & Lesser Antilles (shallow) & Adey \& Burke (1977) \\
\hline Coralline algae & Lesser Antilles (shallow) & Adey \& Burke (1977) \\
\hline Sclerosponges & Jamaica $(70-105)$ & Lang (1974); Lang et al. (1975) \\
\hline \multicolumn{3}{|l|}{ Indo-Pacific Ocean } \\
\hline Pocillopora damicornis & Panama $(0.5-6)$ & Glynn (1976); Glynn et al. (1972) \\
\hline Pocillopora spp. & Galapagos & Glynn et al. (1979) \\
\hline Stylophora pistillata & Eilat $(0-4)$ & Loya $(1972,1976 c)$ \\
\hline \multirow[t]{3}{*}{ Acropora palifera } & Chagos $(0-4)$ & Sheppard (1980a) \\
\hline & N. Great Barrier Reef $(0-5)$ & Veron (1978); Veron \& Hudson (1978) \\
\hline & Lord Howe Is. & Veron \& Done (1979) \\
\hline A. humilis & N. Great Barrier Reef (5-11) & Veron (1978); Veron \& Hudson (1978) \\
\hline A. hyacinthus & Chagos lagoon $(4-10)$ & Sheppard (1980a) \\
\hline Galaxea astreata & Chagos lagoon $(20-30)$ & Sheppard (1980a) \\
\hline Porites californica & Cocos Is. & Bakus (1975) \\
\hline Millepora spp. & Eilat (2) & Loya $(1976 \mathrm{~b})$ \\
\hline Coralline algae & & Adey \& Macintyre (1973) \\
\hline
\end{tabular}

size and total biomass, but which eventually surpass the primary corals in both parameters and have a binding action as well. Subsequent repeated boring and cementation then leads to replacement of the framebuilder by cemented sediment. Coral succession is thus linked with a succession of other processes which have the greatest importance in providing reef substrate.

By this definition, most initial, rapidly colonizing or abundant colonies may be called framework species. It is the role played by a species in certain situations rather than its identity which endows it with the term, and the same species elsewhere may not have a framework role. In several areas, species have been cited as primary framework species. Table 1 lists the more common ones; it is abbreviated since the term has been given different, sometimes ambiguous meanings. However, it illustrates the range involved. In the Indo-Pacific Ocean, most cited examples are branching or encrusting shallow forms, while in the Atlantic Ocean the massive Montastrea spp. are also cited. A fully documented example of framework activity was provided by Shinn (1963). Branches of Acropora palmata orientate into the waves where they gradually coalesce and infil, developing into increasingly solid limestone spurs and eventually into 'reef'. In this case the morphology and growth response of the species to the environment is important. Most cited framework species are those of shallow water in the region of greatest wave energy, but the principle applies as well to deeper areas (Goreau, 1959a). In terms of the species concerned - if not of the process involved - the term is necessarily imprecise.

Unattached species or free parts of usually attached species may have a marked role in providing framework. In lagoons of Chagos below $20 \mathrm{~m}$ (Sheppard, 1981a) dead fungiids provide 'reef nuclei' on areas otherwise unsuitable for coral settlement, upon which increasingly large mounds of coral develop. Goniopora stokesi which reproduces with 'polyp ball' formation (Rosen and Taylor, 1969), similarly provides new reef foundation in these lagoons. Detached, spherical coralla roll from their colony of origin onto soft substrate where they embed and grow, resulting in an extension of the base of the lagoon reef slope over soft substrate. Highsmith (1980a) reported similar reef building by Porites lutea in Enewetak atoll. Here 'accidental' detachment of fragments distinguishes Porites from Goniopora, though with equal success in providing new framework. Although of apparently great 
importance in this respect, these examples are also significant in the process of succession towards mature reef communities. The coral framework on a reef is a community at various pioneering to advanced or climax states; it is discussed later mainly in this context (see next section).

\section{CORAL DISTRIBUTIONS}

The wide range of reef slope types and of constructional species nevertheless shows many similarities in coral population structure. This section considers observations of coral distributions from widespread reefs, identifiying common, even universally applicable patterns. Some causes of pattern are suggested, but the main purpose is to present an outline of the patterns themselves, in order to provide a foundation for discussion of their control later.

The most studied depths on reef slopes are those with relatively easy access, lying below the region of extreme wave action, extending to various depths dictated by local topography or personal choice. During the 1970's descriptive work on reef slopes continued, often in greater detail than previously. Most of those completed since the listing in Stoddart (1969) are shown in Table 2. Only a few very exposed slopes include the region shallower than $5 \mathrm{~m}$, and few include depths beyond $35 \mathrm{~m}$. These regions are examined separately. Within the most studied region, favoured methods have included specifying coral zones, measuring coral cover and especially measuring diversity.

\section{Shallow Reef Slope}

Shallow, very exposed reef slopes are commonly characterised by various erosional and constructional features, penetrated by tunnels, gullies or groove and spur systems. Their nature and form depend both on present exposure and on geological history.

Both Atlantic and Indo-Pacific regions show well developed algal constructions emergent to $0.5 \mathrm{~m}$ or more (Wiens, 1962; Stoddart and Yonge, 1971; Glynn, 1973a; Stoddart, 1973). Strong water movement and high aeration appear necessary for their growth (Doty, 1974; Littler and Doty, 1975) which most commonly results in a ridge running along the reef edge approximately perpendicular to the main wave direction, and in spurs projecting seaward. In the Indo-Pacific Ocean the main builder is Porolithon, while Caribbean counterparts are formed from Porolithon and Lithophyllum (Cribb, 1973; Adey, 1975) or intergrowths of algae,
Table 2. Zonation maps, profiles or descriptions of reef slopes published since Stoddart (1969). Publications containing species lists only are omitted

\begin{tabular}{|c|c|}
\hline Region, site & Source \\
\hline \multicolumn{2}{|l|}{ Atlantic Ocean } \\
\hline 6 generalised reefs & Geister (1977) \\
\hline Florida Middlegrounds & Hopkins et al. (1977) \\
\hline West Flower Garden Bank & Rezak (1977) \\
\hline N.W. Gulf of Mexico & Bright (1977) \\
\hline Glovers Reef, Belize & $\begin{array}{l}\text { Wallace \& Schafersman } \\
\text { (1977) }\end{array}$ \\
\hline Panama & Porter $(1972 a)$ \\
\hline Galeta Point, Panama & Macintyre \& GJynn (1976) \\
\hline Veracruz, Mexico & Kuhlmann (1975) \\
\hline Venezuela & Antonius (1980) \\
\hline Discovery Bay, Jamaica & Goreau (1959a); \\
\hline & Goreau \& Goreau (1973); \\
\hline & Lang (1974); \\
\hline & Land and Moore (1977) \\
\hline Coral Cays, Jamaica & Mergner (1972) \\
\hline Patch reef, Jamaica & Bonem \& Stanley (1977) \\
\hline Puerto Rico & Morelock et al. (1977) \\
\hline Cuba & Kuhlmann (1974) \\
\hline Bonaire & Scatterday (1974) \\
\hline Anegada & Dunne \& Brown (1979) \\
\hline Martinique & Adey et al. (1977) \\
\hline St. Lucia & Roberts (1972) \\
\hline Curaçao, Netherlands & Bak $(1975,1977)$; Van den \\
\hline Antilles & Hoek et al. $(1975,1978)$ \\
\hline Tobago, Cays & Lewis (1975) \\
\hline \multicolumn{2}{|l|}{ Indo-Pacific Ocean } \\
\hline Eilat & Loya \& Slobodkin (1971) \\
\hline Red Sea & Mergner (1971) \\
\hline Aldabra & Barnes et al. (1971) \\
\hline Tuléar, Madagascar & Pichon $(1971,1972,1978)$ \\
\hline Seychelles & Braithwaite (1971) \\
\hline Mauritius & Salm (1976) \\
\hline South India \& Minicoy & Pillai $(1971,1977)$ \\
\hline South India, Sri Lanka & Mergner \& Scheer (1974) \\
\hline Maldives & Scheer $(1972)$ \\
\hline Gan, Maldives & Davies et al. (1971) \\
\hline Chagos & Sheppard (1980a, 1981b) \\
\hline Cocos-Keeling & Colin (1977) \\
\hline E. Indian Ocean & Kohn (1971) \\
\hline Malaya Singapore & Chuang (1977) \\
\hline Indonesia & Sukarno (1972) \\
\hline S. Papua New Guinea & Weber (1973a) \\
\hline Central Solomon Is. & Weber (1973b) \\
\hline Far N. Great Barrier Reef & Veron (1978) \\
\hline N. Great Barrier Reef & Veron \& Hudson (1978) \\
\hline \multicolumn{2}{|l|}{ Bushy, Redbill, Inner Great } \\
\hline Elizabeth Reef & Slater \& Phipps (1977) \\
\hline Lord Howe Is. & Slater \& Phipps (1977); \\
\hline & Veron \& Done (1979) \\
\hline Solitary Is. & Veron et al. (1974) \\
\hline Phillipines & Pichon (1977) \\
\hline New Caledonia & Woodhead \& Weber (1969) \\
\hline N. Marshall Is. & MacNeil (1972) \\
\hline Lakeba, Fiji & Salvat et al. (1977) \\
\hline Fanning Is. & Maragos (1974b) \\
\hline Mckean & Dana (1979) \\
\hline Cook Is. & Stoddart \& Pillai (1973) \\
\hline Cocos Is. & Bakus (1975) \\
\hline Panama & Glynn et al. (1972) \\
\hline \multicolumn{2}{|l|}{ Both regions } \\
\hline $\begin{array}{l}\text { Caribbean, Red Sea } \\
\text { hydroid zones }\end{array}$ & Mergner (1977) \\
\hline
\end{tabular}


Millepora and vermetid gastropods (Scoffin, 1972; Ginsburg and Schroeder, 1973). Similar but larger structures may be caused almost entirely by erosion even where Porolithon exists, such as at Tuléar, Madagascar (Pichon, 1978).

The groove and spur structures, themselves a product of wave energy, wavelength and harmonic (Munk and Sargent, 1948) considerably baffle water movement. Considerable variety of forms and scale exist (Stoddart, 1978), since varying combinations of growth and erosion are involved (Emery et al., 1954; Pichon, 1978). Two series of structures show that they increase in size with increasing wave energy. In Bikini, an algal ridge was absent on a sheltered lagoon reef, poorly developed on moderately exposed reefs to well developed on very exposed reefs (Stoddart, 1969). In Chagos, ridge progression is similar, but algal spurs formed at lower wave energies, existing unconnected by a ridge on both lagoonal and sheltered seaward reefs (Sheppard, 1981b). Below them, similar but smaller spurs of enhanced coral growth continued on from, and matched, each algal spur for an additional $75 \mathrm{~m}$ to seaward. By commencing in deeper water however, they exist in considerably less turbulent water movement. Shinn (1963) observed spurs whose main framework was Acropora palmata which reached the surface in Florida. The exposure conditions in this case appear to be less severe than in Chagos.

It is clear that the more severe the water movement, the greater is calcareous algal cover and construction, and the smaller is the coral component. To what proportion corals are inhibited by the water movement per se or by exclusion by the algae has not been determined. Assessment of this is impeded by the fact that the coral fauna of this extremely exposed region has been little studied. Pichon (1978) found zonation in Madagascar between the surface and $7 \mathrm{~m}$ deep, in which encrusting corals were the first to appear below a denuded zone. In Chagos also, the shallowest parts of spurs were generally devoid of corals except for occasional Stylophora pistillata. Grooves between spurs were largely devoid of corals throughout. Then, about 10 coral species entered in distinct sequence. The presence or absence of Acropora palifera distinguished 2 associations in the region to $3 \mathrm{~m}$ deep. When present, this species was overwhelmingly dominant. Other than this encrusting species, corals of this region were massive or ramose, similar to forms colonising surf areas in the Seychelles (Rosen, 1971b). Immediately beneath the Caribbean algal ridges off Panama also the substrate is devoid of corals (Porter, 1972c). Below less exposed ridges in Barbados (Stearn et al., 1977) a wide range of species grow; including several usually fragile forms. Even here, corals were largely absent on the 'crest' itself.
Generally $10 \%$ or fewer of the total number of reef slope species penetrate the most turbulent region (Pichon, 1978; Sheppard, 1981a). Coral zones which are very shallow on sheltered slopes are depressed on slopes whose prevailing wave action is sufficient to cause algal ridge or groove and spur development. The above studies suggest that soft corals appear to be even more limited in such areas; in Chagos this group appeared exactly where algal spur construction ceased.

Such algal constructions are absent from many slopes where, instead, corals survive up to the intertidal region. Several examples of this exist in studies listed in Table 2. In these shallow areas of both Caribbean and Indo-Pacific regions (e.g. Goreau, 1959a; Loya, 1972) coral zonation is clearly defined, and diversity is higher than at similar depths amongst algal grooves and spurs. But in many such areas water movement is not less than in areas possessing grooves and spurs. This suggests that unsuccessful competition with algae is an important cause of the poor coral performance in the latter.

Direct water movement itself is nonetheless universally regarded as the primary control (see Done, in press for discussion and 'Marine Ecology', Vol. I: Riedl, 1971a, b; Schwenke, 1971). Although the mechanisms causing the shallow zonation are not clear. It has been considered sufficient to assume that zonation is the result of differential but unspecified tolerances to the obvious physical gradient. Foliose forms are indeed generally excluded, but relatively fragile ramose forms are commonly the first to colonise turbulent areas, suggesting that massive physical strength is not the main requirement for existence here. An ability for rapid, initial settlement may be of greater importance, but this and other possibilities remain unknown.

\section{Cover and Zonation}

Most reef slope work commences below this exposure extreme. All but a few coral studies largely exclude major benthic components other than corals. Those which include other groups are especially important for highlighting the polyphyletic nature of succession, zonation and competition.

Of these the most detailed and extensive are studies on algae, corals and gorgonians in 2 transects in Curaçao to $65 \mathrm{~m}$ (Van den Hoek, et al., 1975, 1978). Seven major biotic zones were categorised: 3 extensive coral and 1 gorgonian zone bounded in shallow and deep water by algal zones. Differential physical and grazing pressures especially from Diadema and fish were related to and partially shown to control this benthic distribution. In Eilat also, grazing pressure and 
interordinal or interphyletic competition becomes increasingly important with advancing succession in controlling space partitioning between algae, soft and stony corals (Benayahu and Loya, 1977a). A high variability exists in space utilization, depending to a large degree on life history strategies and creation of new space, the latter caused on reef flats by abiotic factors such as exireme low tides, or by predation and grazing in deeper water.

Most studies focusing on corals combine other benthic groups into categories such as 'soft coral' or 'algae' without the specific distinctions made in the above studies. Patterns of zonation and cover are illustrated in most reef slope studies listed in Table 2. Methods used vary, but most may be grouped into phototransects (Drew, 1977), transect or quadrat sampling, or a combination of both (review: Stoddart and Johannes, 1978). Many reef slopes, especially exposed ones, show an increasing coral cover with depth to about $5-10 \mathrm{~m}$. Then a sustained high cover occurs of $50 \%$ or over to at least $30 \mathrm{~m}$, after which coral cover declines (e.g. Barnes et al., 1970, 1971; Maragos, 1974b; Ott, 1975; Bak, 1977; Van den Hoek et al., 1978; Jokiel and Maragos, 1978; Sheppard, 1980a). In several of these slopes, algal cover exceeds coral cover at the shallow and deep extremes. Considerable variety naturally occurs, some sites having almost no similarity with this pattern (e.g. Loya and Slobodkin, 1971). Onto such cover patterns can be imposed soft coral cover; these contribute most well within the range occupied by stony corals, rarely exceeding beyond it. Sarcophyton sp. occupied up to $80 \%$ cover at $15 \mathrm{~m}$ in Fanning Island (Maragos; 1974b), while values were 2-15\% in Eilat (Benayahu and Loya, 1977a) and 10-20\% between 3-23 m deep in Chagos with localised values occasionally exceeding $50 \%$ cover (Sheppard, 1980a). The stony hydrozaan Millepora spp. also shows a high cover towards the shallow extreme, where recorded (e.g. Loya and Slobodkin, 1971; Maragos, 1974b).

Temporal changes in coral cover may vary $2-3$ fold over periods of a few years in very shallow water (Connell, 1973; Glynn, 1976). Cover changes progressively less with time over increasing depths however. Bak and Luckhurst (1980) examined constancy of cover between $10-40 \mathrm{~m}$ deep at Curaçao; they found that cover by coral and non-living components changed very little over $5 \mathrm{y}$. More importantly though they recognised a considerable flux of substrate category at any particular point, such that, although total cover did not change, spatial rearrangement of each type of substrate was relatively rapid.

Within regions of high coral cover, (a) species show frequency distribution curves which decline exponentially (Loya and Slobodkin, 1971; Goodwin et al., 1976;
Sheppard, 1980a), and (b) many species are abundant in restricted depth distributions. A combination of both factors, together with a large colony size, results in visibly greater cover of certain species in circumscribed areas. These species generally name a 'zone'. Zones may be named after a single or group of species, usually simply the visually most dominant (Wells, 1954; Greau, 1959d; Goreau and Goreau, 1973) or that defined by a cover exceeding $10 \%$ or $50 \%$ (Sheppard, 1980a, 1981c), or defined or confirmed by cluster analysis (Loya, 1972; Maragos, 1974b; Done, 1977). Coral colony morphology defined zones in Aldabra (Barnes et al., 1971), an approach taken to considerable detail with Acropora by Wallace and Dale (1977) on the Great Barrier Reef.

The value of simple zones lies in their aid to orientation on the reef, and in following changes in community structure along changes of environmental gradients. For example, zones may become shallower with proximity to a pass (Barnes et al., 1971) or become compressed with increased exposure (Bak, 1977). Their disadvantage is that much information is lost or masked. They may even be misleading. Goodwin et al. (1976) showed strong associations amongst species often considered characteristic of different zones, such as Acropora palmata and Montastrea annularis. This was caused by overlapping distributions of each, and because each occurs in wider expanses of reef than that in which they dominate. Aggregated distributions on a Caribbean reef slope were also discussed by Dana (1976), while Ott and Auclair (1977) were able to compute more clusters or associations of species than could be readily discernible by sight. Both studies illustrate the inadequacies in only using zones in ecological study.

Other terms taken from plant ecologists are becoming more widely used. These - e.g. assemblages, alliances, etc. (Rosen, $1971 \mathrm{~b}$; Scheer, 1978) - incorporate distributions of greater numbers of species which together denote a set of conditions, and its gradients. Rosen (1971b) formulated 3 assemblages related to exposure, in each of which is a principal community made up of several species. Further, each assemblage contributed differently to reef construction. The phytosociological work of Scheer $(1972,1974,1978)$ is also notable in its multispecies approach to coral communities. In general, more information may be obtained by such methods than by examination of simple zones, though the latter is more rapid.

'Zone' has a different usage in studies of Canton Atoll (Jokiel and Maragos, 1978), referring to areal expanses within and outside the atoll. Zone definition here was also aided by a cluster technique and related to physical controls (see 'Controls on Distribution', p. 94). 


\section{Diversity}

Diversity studies, more than any others, are affected by regional differences in the coral fauna. General or unifying principles must take into account the range of species richness encountered, a point usually overlooked. Diversity studies at Fanning Atoll involved 71 species (Maragos, $1974 \mathrm{a}$, b) that at McKean only 49 (Dana, 1979); it is questionable whether these and others - including the richest Atlantic sites - can validly be compared to diversity studies of areas whose species richness is 4 or 8 times greater. Trends along gradients may be compared, but usually values may not. Our understanding of how species diversity and identity affects other common ecological measures (e.g. cover) is poor, so other methods may also suffer from this constraint.

Two main types of diversity measurements are used in reef studies: (1) number of species or, more commonly, genera, which is common in zoogeographic work (e.g. Rosen, 1971a); (2) indices incorporating measures such as evenness, relative abundance, 'bits' per individual or other 'dubious' (Hurlbert, 1971) parameters. These are common in single-reef studies. Often species number compares well with indices and appears adequate for describing or explaining community differences down a reef slope (Loya, 1972; Porter, 1972a; Connell, 1978), though sometimes it correlates poorly with other indices (Sheppard, 1980a).

Both methods have been used to trace diversity changes with increasing depth. Two fundamental and at first sight conflicting patterns have emerged. Firstly, Wells (1957) and Rosen $(1975,1977)$ present diversity profiles with depth from a variety of sources. These show a general decline of diversity with depth. The second pattern is that of an initial rise to a plateau, followed by a fall. In Eilat, Loya (1972) showed that $\mathrm{H}^{\prime} \mathrm{N}$ diversity increases to $30 \mathrm{~m}$ (the lower limit of the study) and stated that a similar increase occurs in Jamaica to $40 \mathrm{~m}$. In Panama $\mathrm{H}^{1}$ diversity increases to $5 \mathrm{~m}$, remains high to $25 \mathrm{~m}$ and then declines (Porter, 1972a). A similar rise to a peak between 10-22 m followed by a fall occurs with species richness down reef slopes of Chagos (Sheppard, 1980a), to some extent in Fanning (Maragos, 1974b), in Jamaica (Goreau and Goreau, 1973) and on slopes in the Central Great Barrier Reef (unpubl.). This curve (Fig. 2) was also generated from a model based on known influences on coral growth by Chappell (1980) who illustrates possible causes for the initial steep slope and subsequent more gentle slope. The ascending curve of Loya (1972) may represent the initial part of this curve; and in Eilat too, a decline in diversity might eventually be recorded. No clear pattern exists in Reunion (Bouchon, 1981), while a clear exception is McKean

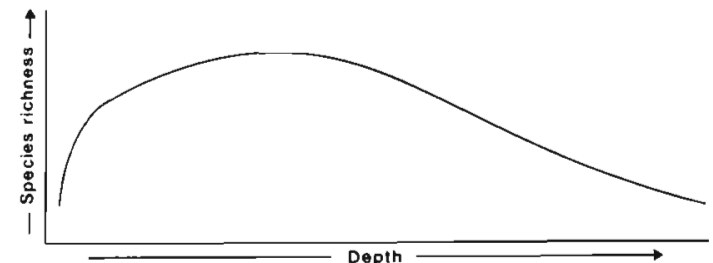

Fig. 2. Generalised diversity curve (diversity index or species richness) reflecting pattern found on the majority of studied reef slopes

Island (Dana, 1979) with a general fall in diversity from a peak just below low water. This may have been due to the fact that sampling frequency below $18 \mathrm{~m}$ was only about a fifth of that in shallower water, which was not sufficiently allowed for; or it may have been due to the very low overall diversity of McKean Island (49 species). Possibly, this reflects recruitment difficulty; it illustrates the earlier-mentioned caution regarding the comparison of patterns between sites with numerically vastly different faunas.

The 2 basic patterns, the general decline and that represented by Fig. 2, are not necessarily contradictory. The same data may fit both patterns. For example, Loya's (1972) data - H ' $\mathrm{N}$ diversity rising with increasing depth to $30 \mathrm{~m}$ - was plotted by Rosen (1977; his Fig. 1) to show a decrease in genera with depth. The explanation may lie with the other parameters of the index and with the fact that most genera contain several species whose depth ranges are less than that of the genus as a whole. Dana (1979) suggested colony density was one influence, and that what Loya (1972) had demonstrated was an increase of density rather than diversity. Whether true or not, it does not apply to the curve from Chagos where collections were unbounded by quadrats or line transects and hence density-independent, yet still resembled Fig. 2. Further, the steepness of the decreases shown by Rosen (1975, 1977) may, in many cases, be intensified by disproportionate collection from shallower locations.

Several fluctuations caused by local topography and climate regimes may be superimposed onto these curves. Localised increases in diversity may result from ledges and terraces (Porter, 1972a, c) while substrate slope and consequent differences in sedimentation are important (Loya, 1972, 1976a).

As a broad generalisation, the greatest number of species and the highest diversity of corals occurs, in most studies, about a quarter of the way down the total hermatypic depth span.

\section{Reproduction, Dispersal, Settlement, Succession}

Reproductive studies of corals earlier this century revealed the complexity of the subject (Marshall and Stephenson, 1933), but in contrast to the wholesale use 
of diversity and cover measurements only a few authors have amplified knowledge of these fundamental aspects of coral populations.

There is a wide variety of reproductive timing in corals. Currently, evidence exists of lunar and seasonal periodicity, sometimes both within one species (Stimson, 1976, 1978) and of extended reproductive periods with diurnal plankton release (Rinkevich and Loya, 1979a, b). The same species may differ in these respects between sites also. Stimson (1978) provides a summary of many earlier studies, as well as evidence of a relationship between planulation and depth in some cases. Thus several factors control this early, vital stage of the life cycle, but their ecological significance is not yet determined.

Length of the planktonic phase shows similar between-species and between-site variance. Stylophora pistillata planulae may settle after $48-120 \mathrm{~h}$, with occasional pelagic lengths of $35 \mathrm{~d}$, while Pocillopora damicornis planulae remain pelagic for $7-18 \mathrm{~d}$, depending on location (Rinkevich and Loya, 1979a, b, and citations therein). Such variations may be of less importance to reef ecology however than to understanding zoogeographic patterns.

Immediately prior to settling, planulae show marked ability for substrate selection (Yamaguchi, 1973; Stimson, 1974; Schuhmacher, 1977a). Whereas they first exhibit positive phototaxis, larvae of Pocillopora damicornis and Favia fragum later reverse this to select dark crevices (Harrigan, 1972; Lewis, 1974a). Buss (1979) cites some older works which illustrate photonegativity, substrate selection, or gregarious settling behaviour. Where biogenous limestone exists amongst granite, coral larvae select the former (Schuhmacher, 1977a). On Barbados reef crests, 3 out of 4 species showed contagious or non-random distribution. Planulae of Favia fragum and Agaricia agaricites were gregarious and tended to settle where conspecific colonies existed (Lewis, 1970, 1974a, b). $P$. meandrina, however, dispersed uniformly (Stimson, 1974) possibly because larvae selected unshaded areas away from existing colonies, i. e. a competition avoidance response. Harrigan (1972) showed substrate preference towards surfaces with a covering of microorganisms and algae in Pocillopora, Favia, by contrast, preferred unfouled surfaces (Lewis, 1974a). A curious substrate selection is attributed to Montipora berryi which settles in tunnels excavated in itself by the bivalve Lithophaga curta. In his description of this process, Highsmith (1980b) hypothesizes a mechanism of reciprocal larval recruitment and points out the refuge found in the arrangement by both partners.

In most cases the effect of larval selection and settlement on mature colony distribution is unknown. Its importance though is suggested by Bak and Engel
(1979) who recorded densities of juvenile and adult colonies in 4 zones between 3 and $37 \mathrm{~m}$ deep on Caribbean reef slopes. Many species showed preferential settlement in one or more zones, with adult distribution mirroring that of juveniles. The commonest juvenile, Agaricia agaricites, revealed a changing preference of substrate slope with depth, from more vertical slopes in shallow water to horizontal surfaces in deeper water. Juvenile densities varied greatly between species, reflecting the wide variety of life strategies employed. Interspecifically aggressive corals, capable of long life and with high capacities of regeneration and sediment rejection, had low juvenile densities (e. g. Montastrea spp.); in contrast, subordinate species with poor regeneration and sediment rejection capacities (e.g. Agaricia agaricites) had juvenile densities 2 orders of magnitude greater.

Fragmentation of mature colonies has been underestimated as a means of reproduction and dispersal. The role of this in Porites lutea (Highsmith, 1980a) and Goniopora stokesi (Sheppard, 1981a) was mentioned under 'Reef Slope Structure and Coral Framework' (p. 84). Highsmith et al. (1980) found that an average $39 \%$ of fragments or detached colonies survived a hurricane in Belize, survival favouring larger fragments. Apart from the importance to colony dispersal these authors suggest that such events cause redistribution of crowded colonies and an increase in the long term calcification and growth of the reefs on which such periodic disturbances occur. Acropora palmata was especially affected, and fragmentation was suggested as the main form of reproduction and dispersal for the species in Belize. Further, Highsmith (pers. comm.) has observed fragmentation in Panama, where he suggests that the growth forms of several species seem designed to increase the probability of breakage, and hence dispersal. A. cervicornis likewise is heavily dependent on fragmentation for its propagation (Gilmore and Hall, 1976; Shinn, 1976; Tunnifcliffe, 1981). Replacement of tissue and repair of damaged skeleton is usually efficient (Fishelson, 1973; Loya, 1976e; Bak et al., 1977; Bak and Steward-Van Es, 1980) so that even moderate to severe damage need not be greatly limiting. After severe mechanical damage on Indian Ocean reef slopes a majority of species reattached and continued to grow (Sheppard, 1980b). Indeed, free-living parts of usually attached corals are common amongst many species, whether caused by breakage or by more deliberate detachment (Glynn, 1974a; Pichon, 1974, 1978; Highsmith, 1980a; Highsmith et al., 1980; Sheppard, 1981a). Highsmith (1980a) also points out the competitive advantage given to the detached coral fragment which survives on soft substrate. In shallow areas particularly, it is a significant means of dispersal which has a profound bearing on the coral community. 
Following successful settlement, early and rapid initial growth improves the chance of success. But conditions which are ideal for this in corals are equally advantageous to competitors, particularly algae. Birkeland (1977) suggested that since faster growing, fouling organisms respond more quickly than corals to increased light and nutrients, coral survival may improve in water which is deeper, darker and poorer in nutrient than in shallow water where corals may be more easily excluded. He suggested further that as light and nutrient input decrease, the total community growth decreases but with a resultant increase in the chances of corals to reach a refuge in size.

Schemes of early coral succession may be obtained from artificial substrates. Although temporally only a minute part of the succession sequence, that observed is the important initial stage. Goren (1979) found that most initial colonisers on polythene panels in the Red Sea were mobile species; less than $4 \%$ were coelentrates. However, since many larval species are selective in their substrate such results may have limited value.

Artificial reefs of wood, stone or concrete have long been known as sites of increased biota (Colunga and Stone, 1974). Although these differ semantically and genetically from limestone reefs, their successions may reflect those on limestone. In the Red Sea, Schuhmacher $(1974,1977 a)$ observed succession on harbour moles over 6.5 y. Like Goren (1979), and Peyrot-Clausade (1977) who observed faunal changes in net bags of coral fragments, he found that corals were not early colonisers. Algae, polychaetes and molluscs settled first. Corals appeared after one year, preferentially settling on biogenic limestone rather than on the granite of the harbour mole. Pioneering corals included Stylophora pistillata, Pocillopora danae,
Cyphastrea microphthalama, Favia favus, F. laxa, Porites sp. and Millepora spp. A high mortality of young colonies was evident, each death providing enlarged substrate for the increasingly diverse fauna. On new, deeper substrate in Chagos, Euphyllia spp. and Acropora spp. were early colonisers, followed by faviids and mussids (Sheppard, 1981a). An alternative succession, or interruption to it, occurred if the aggressive Galaxea astreata settled and dominated the substrate.

Schuhmacher (1977a) formulated 4 stages of succession: start phase (algal settlement); preparation phase (non-coelenterate limestone deposition); pioneer coelenterate phase and, finally, framework binding. Processes of each phase continued into the next, and bioerosion commenced before the binding phase.

Fig. 3 shows a synthesis of succession (Schuhmacher, 1977a; also: Grigg and Maragos, 1974). Diversity and cover increase during colonisation reaching a peak before climax is attained. The time required in Hawaii for a disturbed area to match adjacent control areas was $20 \mathrm{y}$ in exposed sites and $50 \mathrm{y}$ in sheltered sites, the difference being explained by constant interruptions in the former, which kept the control sites themselves further from a climax state. Succession measured by change in species diversity has been recorded following a catastrophic low tide on a reef flat (Loya, 1976b), and following an Acanthaster plague on a reef slope (Porter, 1972b). Here too diversity rose until space became limiting, after which diversity fell. Repeated interference, environmental and biological, tends to interrupt these processes, keeping the diversity higher and at a subclimax state. Common to most reports of successional events is a high mortality rate of juvenile, pioneering corals. Fig. 3 reflects these features while being necessarily imprecise on time scale.
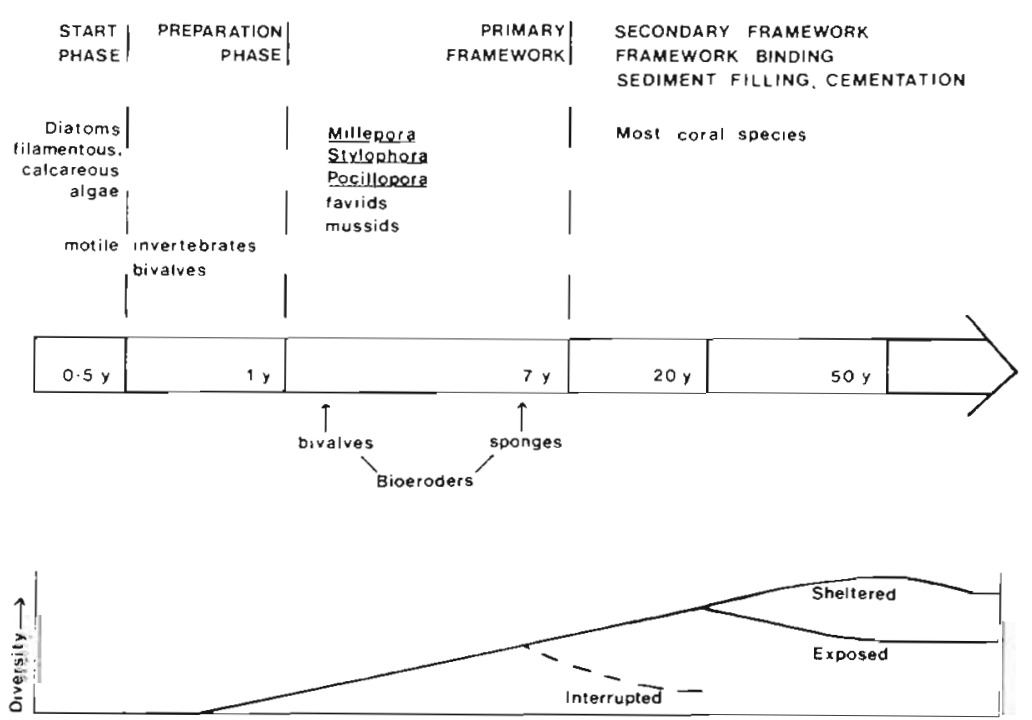

Fig. 3. Schematic summary of coral succession events. Largely based on Schuhmacher $(1977$ a), with additional information from other authors 
Where very large areas have been affected, for example by earthquake or hurricane (Stoddart, 1965 , $1972,1974)$, severe disturbance may result to reef slope communities. Depending on whether or not a 'threshold' level of damage is passed, recovery of shallow areas may be prolonged at best. Presumably, the degree of damage and its frequency has a bearing on whether net, long term destruction or beneficial dispersal of a coral population occurs, though the question has yet to be resolved.

\section{Deep Reef Slope}

Studies of deeper regions of coral reefs are few. Most SCUBA investigations terminate at around $20-40 \mathrm{~m}$, either for safety requirements or because reef substrate changes to sand. Until relatively recently it was assumed (Stoddart, 1969) that maximum growth occurs above $10 \mathrm{~m}$, with a limit for most species of $25 \mathrm{~m}$.

Nowhere has study of the deep reef been more detailed than at Jamaica. Goreau extended SCUBA studies of reefs at Discovery Bay to $65 \mathrm{~m}$ (Goreau and Goreau, 1973), and in the same area, several reports resulted from a survey by submersible. This reef shows a fairly gradual slope to about $60 \mathrm{~m}$ complicated by a series of buttresses, followed by a steep fall to about $120 \mathrm{~m}$, then followed by a less steep, highly sedimented slope to over $300 \mathrm{~m}$ (Land and Moore, 1977; Goreau et al., 1979). Work here has revealed new diagenically and ecologically important species of corals, algae and sponges (Goreau and Graham, 1967; Goreau and Wells, 1967; Lang et al, 1975), proving that many hermatypic corals can live in abundance to $80 \mathrm{~m}$ and occasionally to over $100 \mathrm{~m}$. Coral framework construction continued to $70 \mathrm{~m}$ (Lang, 1974) though Goreau and Wells (1967) suggest that in less steeply shelving sites diverse coral may penetrate to $100 \mathrm{~m}$. Of great interest was the discovery that framework construction continued to $105 \mathrm{~m}$ by sclerosponges which grew under overhangs, and by demosponges on vertical surfaces (Hartman, 1973; Lang, 1974; Lang et al., 1975). Some zonation of these on the cliff was apparent. The net result of the coral primary framework to $70 \mathrm{~m}$, sponge framework from 70-105 m, sediment effects and calcareous algae - which on this reef produce more $\mathrm{CaCO}_{3}$ than corals (Goreau and Goreau, 1973) - is that to $105 \mathrm{~m}$ deep the reef is actively accreting to seaward (Land and Moore, 1977).

Other submersible studies revealed a lower limit of hermatypic corals at $90 \mathrm{~m}$ off the Bahamas (Porter, 1973), significant coral cover to $70 \mathrm{~m}$ at British Honduras (Ginsburg and James, 1973; Glynn, 1973a; James, 1977), and luxuriant coral at $60 \mathrm{~m}$, with some at $107 \mathrm{~m}$ in Andros (Bushy et al., 1966, in Glynn, 1973a).
Curaçao, also in the Caribbean, harbored scattered corals from 27-50 m amongst a conspicuous algal flora. Few corals grew at 55-60 $\mathrm{m}$, though a largely soft substrate was partly responsible (Van den Hoek et al., 1978). In all cases the deepest coral communities are of plate-like or leafy forms, though small massive forms are present.

Corals of similar morphology and families are the main colonisers of deep Indo-Pacific reefs. Wells (1954) defined an Echinophyllia zone between 18-91 $\mathrm{m}$ in Bikini. In the Ryukyu Islands, fairly high coral cover occurs to $50 \mathrm{~m}$ or more with colonies continuing to $100 \mathrm{~m}$ (Yamazato, 1972). In Chagos, Indian Ocean, a zone of Echinophyllia, Mycedium, Pachyseris and Leptoseris was defined between 27-45 m (Dinesen, 1977); similar corals led Pichon (1978) to name a comparable depth region in Madagascar the 'Agariciidae and Pectiniidae zone'. Zonation was charted in Chagos to $60 \mathrm{~m}$ (Sheppard, 1980a); at least 9 species appeared in distinct zones below $40 \mathrm{~m}$ ( 2 commencing only below $50 \mathrm{~m}$ ), continuing in relative abundance to $60 \mathrm{~m}$. Leptoseris mycetoseroides still maintained a cover of hard substrate of over $10 \%$ at $60 \mathrm{~m}$; however with soft substrate becoming increasingly important, coral framework was superceded by that of algae and sponges below about $45-50 \mathrm{~m}$. Where substrate permitted, corals flourished to $65-70 \mathrm{~m}$ which was the limit of vision.

In Chagos, about $12 \%$ of reef slope species existed almost exclusively in the deep reef, below about $45 \mathrm{~m}$ (Sheppard, 1981a). A further $18 \%$ of species penetrated the region to varying degrees from their shallower, optimum levels. Less than $50 \%$ of species found below $20 \mathrm{~m}$ in Eilat occurred in shallower depths (Loya, 1972) and a very similar proportion may be calculated for Jamaican corals (Goreau and Wells, 1967).

Very deep, detailed studies to compare with those of Jamaica have yet to be performed in the Indo-Pacific Ocean.

A lower limit to hermatypic growth is affected by two main factors. First is the increasing presence of sand which forms in large quantities in shallower areas and which flows down-slope, forming increasingly large sand patches. In Jamaica (Goreau and Goreau, 1973) chutes and buttresses channel the flow, maintaining large areas of hard substrate. In most other areas cited above, sand patches are a main cause of cessation of coral growth except on very steep slopes. This is a function of topography which, because of its feedback with growth, may be partially self sustaining. The second factor is light, which is dependent on water clarity. This is again compounded with slope, a steeper slope shortening the range of individual corals (Goreau and Wells, 1967). 
Goreau et al. (1979) suggest that a shallower lower limit to hermatypic growth is one distinguishing feature of Indo-Pacific reefs; however, this may have resulted from the paucity of observations in the latter. A few species of corals at these depths may be species which exist also in shallow regions, though others of particular families are only found in such areas where their leafy shape or physiological adaptation is suitable for the poor illumination.

\section{Cryptic Habitats}

The darkest reef habitats to have received close attention are caves and overhangs. Those of Tuléar include topographically complex sidewalls of spurs, tunnels and galleries. The area is shallow so that strong water movement complements light intensity as an environmental control, the skiaphyllic community showing changes, for example, near blowhole apertures. Substrate relief is such that wide variation occurs in total light received and in its distribution throughout the day over very small distances (Jaubert and Vasseur, 1974). Scleractinian diversity is much lower than that of sponges and coelenterates; hermatypic species survive only in areas receiving over $5 \%$ surface light. Dendrophyllia elegans and Tubastraea aurea are common (Vasseur, 1974) existing in a narrow irradiance band of about $0.5-2 \%$ surface light, while Culicia cuticulata and Balanophyllia sp. exist in a lower, still narrower band of $0.02-0.05 \%$ surface light. Scleractinians were not found in the darkest areas. These caves and smaller cryptic areas support numerous species over a large surface area, adding markedly to the reef biomass (Vasseur, 1977).

Caves of the Great Barrier Reef region are the only others to have been studed in detail (Dinesen, 1980a). Again, Tubastraea spp. and Dendrophyllia spp. were commonly encountered; other ahermatypes were rare. A rich coral fauna included most families of hermatypes; Leptoseries was the second commonest genus. This diversity is much greater than that at Tuléar, even allowing for the higher diversity generally in the Australian region. Measured light levels were no higher in caves of the latter. Dinesen (1980a) noted little clear zonation, although some species had preferred habitats within the caves, possibly again due to the complexity of illumination patterns in such areas. Three broad, overlapping groups were: (1) corals generally skiophilous, or confined to low light by competitive exclusion or possibly because they are actually photophobic; (2) preferentially cavernicolous corals which prefer shallow, shaded habitats; (3) shade tolerant corals whose wide habitat ranges enable them to penetrate shade. In almost all cases, hermatypic colonies adopted encrusting or laminar morphology.

\section{CONTROLS ON DISTRIBUTION}

Considerable imbalance exists in the degree to which each of the following presumed controls of coral distribution has been studied. Some physical parameters, (e. g. sediment, temperature) were early subject to detailed study, largely in conjunction with reef flat work. Some biological controls, such as predation and interspecific competition, still await comparable attention. Light, while well considered in coral physiology, has only lately been studied as a potential factor controlling distribution on reef slopes. Early views on depth limits caused by lack of light have been shown to be erroneous, for example (last section), and current research emphasizes the need for critical reassessment.

\section{Control by Nutritional Requirements}

The fascinating problem of the relative importance of autotrophic and heterotrophic nutrition has been the centre of much research. It is discussed here insofar as nutritional requirements affect distribution. Two interrelating factors are important: the degree to which each coral is dependent on autotrophic or heterotrophic feeding, and the gradients on the reef of the energy sources for each mode: those of light and particulate food material.

Goreau et al. (1971) emphasise heterotrophic nutrition, pointing out the generally well developed structures of corals for prey capture. Johannes (1974) by contrast stresses their well developed adaptations for autotrophic feeding (but suggests that, since corals use pre-formed compounds in both methods, the terms are erroneous and that both forms are heterotrophic). Laboratory tests where corals were fed or starved, illuminated or kept in darkness, indicate that survival can occur without light, but not without zooplankton, at least for 9 months (Yonge, 1973). Johannes (1974) by contrast reports that corals grow as fast in filtered as in unfiltered water, while Franzisket (1970) also demonstrated the importance of light to survival in hermatypes. With juvenile Favia fragum both zooplankton and light are essential (Lewis, 1974c). However, tentacle expansion and hence much of the particulate food capture is itself under the influence of light, both directly and possibly via a zooxanthellae-connected route (Lasker, 1976, 1977, 1979; Sweeney, 1976), so the 2 modes of nutrition may not be as separate as implied. 
Particulate Feeding

The fact that hermatypic corals capture and utilize particulate food to some degree using several mechanisms is not in doubt, though zooplankton may range in importance from being energetically very significant, as with Montastrea cavernosa (Porter, 1974a), to being a minor energy source in Porites lobata (Johannes and Tepley, 1974).

However, the usually low density of zooplankton on most reefs has led to doubts on the sufficiency of this energy source. Thus it has been suggested that particulate capture is vital, more for providing essential nutrients than for energy (Johannes et al., 1970). But zooplankton is not the only food captured; bacteria and dissolved organic and inorganic matter may be utilized too (Sorokin, 1973; D'Elia and Webb, 1977). Small particles which can be trapped by mucus threads and nets (Lewis and Price, 1975; Lewis, 1976, 1977) greatly extend the scope of heterotrophic feeding, particularly as such particles may be considerably more abundant than the zooplankton (Glynn, 1973a, c; Moriarty, 1979).

Although this greatly extends the number of food sources for corals, their calorific content may still be inadequate (Porter, 1974a; Muscatine and Porter, 1977), though Coles (1969) showed that some corals could obtain all their needs from heterotrophism under forced conditions.

Where such food is limiting or nearly so, it may influence coral distribution. For it to do so, it must also show gradation. At present there is scant data to show that the supply of zooplankton, finer particulate matter or dissolved matter is zoned vertically either permanently or markedly down reef slopes, though Emery (1968) found different planktonic composition and abundance in different reef areas. A special group of 'demersal zooplankton', wide in taxonomic composition, reveals diurnal vertical migration. These forms are more numerous over branching coral than over sand and appear to shelter in interstitial crevices in the day, coming to the surface overnight (Aldredge and King, 1977; Porter et al., 1977). Although this influences the time of day when corals capture prey most effectively, its effect on coral distribution is unproven.

With ahermatypic corals, vertical, food-related zonation may be clearer. Although these corals are more common in the deeper regions of the reef and beyond in Aldabra (Barnes et al., 1971) and Rodriguez (Faure, 1974) the upper limit of Dendrophyllia rises towards the surface in the vicinity of reef passes. Here, increased particulate matter sweeps nearer the surface, enabling the species which is entirely dependent upon such particles to grow abundantly in depths as shallow as $10 \mathrm{~m}$. On reef slopes of Chagos, even in the absence of adjacent passes this species sometimes existed in a zone between 23 and $40 \mathrm{~m}$. Hermatypic coral zonation was unchanged (Sheppard, 1980a). This possibly reflected a zone of improved food supply for Dendrophillia. It is reasonable to suppose that such species are more sensitive and responsive to changes in particulate food abundance since they are wholly dependent on it.

It appears unlikely that there is much influence on broadscale vertical distribution of hermatypes by their particulate food supply because the latter shows no confirmed zonation in most cases, and because hermatypes are buffered from transient deficiencies by their dual modes of feeding. Small-scale controls on coral distribution may be exerted if the presence of an effective feeder like Montastrea cavernosa causes a 'plankton shadow' down-current of it (Porter, 1974a, 1976). On shallow reef flats however, particulate densities may show horizontal gradients (Glynn, $1973 b, c)$

\section{Light}

Even the most voracious feeders use photosynthates produced by their zooxanthellae. Whereas the heterotrophic sources are apparently not overly abundant, and influence hermatypic coral distribution only slightly or ambiguously, light - the basis of autotrophic nutrition - is both abundant in shallow water and shows a well-studied gradient. Whereas it is difficult to find sufficient sources to satisfy full heterotrophic nutrition, no such difficulty exists for the autotrophic mode on shallow reefs at least. Only photosynthesis appears to be capable of providing abundant fixed carbon in corals. Wethey and Porter (1976a) showed that on sunny days as little as $30 \%$ of that fixed in some species can satisfy their energy needs.

Illumination at any particular wavelength falls approximately logarithmically with depth (Jerlov, 1970). Total illumination thus decreases in a complex manner, and light received by any colony is considerably affected by numerous additional factors such as substrate type and slope (Brakel, 1979). The greatest depth at which symbiotic corals can be supported varies between 60-100 m, given adequate substrate (see 'Coral Distributions'). However, despite the strong gradient of illumination down any one reef and the marked effects of light on several aspects of coral biology, the depth distribution of coral species, their morphologies and zones parallel the light gradient only loosely or apparently not at all. In their review on coral growth Buddemeier and Kinzie (1976) state that light is one of the most poorly understood controls despite being amongst the most studied. The same applies to its influence on coral distribution. 
Wethey and Porter (1976a, b) demonstrated that Pavona praetorta shows adaptation to ambient light such that at $25 \mathrm{~m}$ the species' photosynthetic mechanism saturates at less than half the radiant flux required by the species in $10 \mathrm{~m}$. Stylophora pistillata also exhibits adaption to low light (Falkowski and Dubinsky, 1981) due to increased chlorophyll and more efficient light utilization in shade-dwelling colonies. This may be widespread in hermatypic corals since the same species of zooxanthellae is common to all species (Taylor, 1974). Thus deeper living corals may satisfy their energy demand by photosynthesis as effectively as shallower dwelling corals, despite twofold or even fivefold differences in the light level (Barnes and Taylor, 1973; Wethey and Porter, 1976b). In some species carbon fixation declines with depth. but so does their respiration (Davies, 1977, 1980).

The siphonaceous green alga Ostreobium is another photosynthetic component of corals, living in the corallum below the polyp tissue. Formerly believed to be of great photosynthetic importance to the coral fOdum and Odum, 1955) its productivity may have been overstated (Kanwisher and Wainwright, 1967; Yonge, 1972). This alga also shows adaptation to low light (Halldal, 1968).

Thus although illumination has a strong gradient, on many reefs its value remains above the compensation point for photosynthesis to depths of 30 or $40 \mathrm{~m}$ (Kanwisher and Wainwright, 1967; Svoboda, 1978). Thus autotrophy alone may provide adequate energy, at least to depths of $40 \mathrm{~m}$ or more, and 'niche width of a coral species with respect to light per se is not limited by its zooxanthellae' (Falkowski and Dubinsky, 1981). Deeper, where illuminance levels fall well below compensation values, coral community changes are most marked, but have unfortunately been largely inaccessible for experimental work. The indication is that pigments, or both pigments and zooxanthellae density, change with depth to maximise light utilization (Dustan, 1979; Falkowski and Dubinsky, 1981). Zooxanthellae density is controlled by the coral host (Drew, 1972; Kevin and Hudson, 1979) so that the coral itself is not entirely passive in this respect.

Control over coral distribution by their nutritional requirements is thus poorly understood because of both the dual nature of that nutrition and the differing degree to which some species depend on each mode. Porter (1976) used the differing morphologies of Caribbean species to postulate a gradient along a heterotrophic - autotrophic axis. The morphology of each species indicated its position along the axis; heterotrophism was defined as being related to polyp diameter and hence zooplankton capture, while autotrophy was considered a function of the surface/volume ratio and thus light interception ability. No 2 coral species occupied the same position along both axes, and clusters into Families occurred. This finding was supported by an experiment where light was excluded for several weeks from $20 \mathrm{~m}^{2}$ of reef but where water circulation continued. Small polyped Acropora cervicornis bleached first, species with medium-sized polyps bleached later, while large-polyped species remained unaffected (Rogers, 1979).

Some reservation of Porter's (1976) method of deriving the 2 axes may be justified. For example, some separation could be obtained using non-symbiotic species alone (e. g. encrusting Rhizangiids, the small massive Tubastraea and the ramose Dendrophyllia). Further, cave dwelling hermatypes tend to have small polyps (Dinesen, 1980b). In Porter's scheme these depend mostly on light which is scarce in this habitat. Nevertheless, Porter's (1976) scheme is a very useful approximation, illustrating the trophic resource partitioning that surely exists between corals.

It is insufficient to regard corals in isolation in this respect. Reef zoanthids similarly derive their nutrition from both modes (Sebens, 1977), as do alcyonarians and several others. Partitioning may exist between octocorals and scleractinian corals since the former appear to depend more on direct absorption of organic matter and less on prey capture than the latter (Mariscal and Bigger, 1977).

\section{Other Light Related Distributions}

The proven link between light and calcification has led to several studies on coral morphology and zonation of different morphological types. Coral shapes range from a hemisphere to a flat leaf or encrusting sheet, or from a maximum to minimum skeleton per unit tissue (e. g. Barnes, 1973).

The lower skeletal deposition per unit tissue as light decreases may be marked. Synaraea convexa illustrates this, changing from branching to leafy forms with increasing depth (Jaubert, 1977). The deepest extreme of even the leafy form is finally arrested when the photosynthesis/respiration ratio falls to unity. Few species exhibit this range of shape, though several others - such as Porites asteroides (Roos, 1967) - show at least some distinct forms. In Jamaica, Montastrea annularis exhibits a marked bimodal, vertical distribution of shallow massive forms and deeper flattened forms, separated by a region at about $20 \mathrm{~m}$ where the species is sparse (Dustan, 1979). The change in morphology in this species is a result of slowed vertical but not horizontal growth (Dustan, 1975). To explain the bimodal pattern, Dustan noted that the impoverished mid-region marked the asymptote of the light attenuation curve and the extinction of much of the light 
spectrum. He suggested 2 ecotypic races of zooxanthellae with different degrees of photoadaptation, permitting extension of the species range. Unfortunately, total coral cover over the full range is not considered, so other possible reasons for the sparsely populated midregion are not effectively discounted. Also the changing shape of this coral with depth has been modelled by Graus and Macintyre (1976) who suggested that genetic differences are not required to explain the latter.

Given that photoadaptation occurs to the extent that nutrition can be satisfied over such a depth range, it is still not clear why such differences in morphology are needed or how they come about. Calcification in corals falls very much more slowly than photosynthesis as light decreases, and even dim light has a considerable stimulating effect (Drew, 1973). Indeed, in some species such as Agaricia agaricites calcification per unit tissue is $\mathrm{g}$ re a te $\mathrm{r}$ in deeper $(24 \mathrm{~m})$ than in shallow (13 m) water (Bak, 1976). Wethey and Porter (1976a) suggest that if the photosynthesis-calification mechanism also photoadapts, then an alternative reason for the morphological changes should be sought.

Further anatomical effects associated with light decrease are a greater spacing of polyps in Montastrea annularis (Dustan, 1979) and Leptoseris spp. (Dinesen, $1980 \mathrm{~b})$ which results in an increase of coenosarc area and decrease of tissue mass $\mathrm{cm}^{-2}$, thus lowering the compensation point. Fine structure of coralla may also be affected (Wijsman - Best, 1974).

Several reef invertebrates are sensitive to the $u-v$ component of sunlight (Jokiel, 1980). The high levels of this radiation in shallow water may be an important control. Weaker intensities, however, may have a reverse effect: polyp pigments fluoresce, converting the $\mathrm{u}-\mathrm{v}$ component into photosynthetically useful wavelengths (Kawaguti, 1969)

\section{Control by Sediment and Water Movement}

Sediment and water movement exert marked biological and geological effects on reefs (Stoddart, 1969). The magnitude of each acts to some degree reciprocally in that the latter prevents settlement of the former (e. g. Marshall and Orr, 1931; Bakus, 1968). Thus sedimentation, an important control of coral growth and distribution, is itself controlled in part by wave energy and water velocity. Around Grand Cayman and Barbados (Murray et al., 1977), for example, highspeed currents lose their carrying capacity in the lee of the islands, depositing sediment which is further worked by wave action, resulting in a paucity of reefs in these areas. Within Canton Atoll lagoon the interre- lated effects of these factors are clearly shown (Jokiel and Maragos, 1978). With increasing distance from the single pass, water motion decreased, sedimentation increased, and the coral population declined in richness and depth penetration. Data analysis strongly supported the view that these physical controls exert major influence on coral communities in low-movement, high-sedimentation areas and on the very exposed, shallow seaward sites, but that biological interactions have greater influence in the more benign conditions elsewhere.

Although sediment and water movement commonly act together, they are treated separately here.

\section{Sedimentation}

Sediment probably affects corals at all life stages, reducing light, inhibiting settlement, and causing energy expenditure in sediment rejection. Fourteen fungiids from soft substrates generally employ 1 or more of 3 principal methods of rejection: passive rejection from cupolate, steep-sided forms, tissue distension which causes a steep side to result, and ciliary transport of mucus-entrapped particles, a feature evident in the first 2 cases also (Schuhmacher, 1977b). To these, tentacular action by many genera may be added (Hubbard and Pocock, 1972). Diaseris distorta may also direct jets of water at the sediment (Hubbard, 1972). Fungiids using ciliary action alone were least able to resist enduring sedimentation, possibly due to exhaustion of mucus-secreting cells. In free corals, overall rejection capacity and sediment grade influences their distribution on the reef (Pichon, 1974).

The hard-substrate species Montastrea cavernosa shows 2 phases of sediment rejection: a passive phase when sediment, especially fine particles, flows off the convex surface, and an active phase requiring energy (Lasker, 1980). Colony morphology affects the former and hence the energy required to actively clear sediment. This species may be particularly efficient at sediment rejection. It was dominant on a reef affected by sedimentation in Puerto Rico (Loya, 1976a). Whereas in clearer water it is less common than Montastrea annularis, its greater sediment rejection ability elevated it here to the position of main framebuilder.

Both clear water (10-15 m visibility) and turbid water ( $2 \mathrm{~m}$ visibility) exist in relatively close proximity in Fanning Atoll lagoon, the suspended $\mathrm{CaCO}_{3}$ loads being $1 \mathrm{mg} \mathrm{l}^{-1}$ in the clear central area and 4 times this value nearer the perimeter (Ray and Smith, 1971; Smith et al., 1971). Both areas have a muddy bottom, though reefs actively grow in each. Those in the turbid area, however, have a coral cover of $31 \%$ - half the value for clear-water reefs. Of the living coral colonies 
in turbid water, $55 \%$ are ramose, whereas $10 \%$ are ramose in the clearer reefs. The reef morphologies themselves differ, those in turbid water having less steep sides. Illumination does not appear to be restricting in either area, and differences may be due to sediment rejecting properties of the different corals.

This bears out the view that a ramose shape is well adapted to surviving siltation (Yonge, 1973), probably by passive means, and thus is common in very deep colonial ahermatypic species (e.g. Wells, 1957; Squires and Keyes, 1967). However, Marshall and Orr (1931) showed that corals with large polyps are most efficient in actively removing silt. Such forms are seldom ramose. Thus several strategies exist amongst corals for sediment rejection, with varying degrees of passive and active processes. In Palk Bay, India, the small-polyped, ramose Acroporidae and Pocilloporidae were amongst the first to disappear on the shoreward, heavily sedimented side of the reef, exist. ing only on the more exposed, less sedimented seaward side (Píllai, 1969). Nowhere was exposure extreme. The species which disappeared, however, were those which usually contribute strongly to framework construction; hence their absence may be responsible for the minimal growth of this reef.

The survival of mostly ramose forms in Fanning Atoll lagoon but of large-polyped, non-ramose species in Palk Bay may represent responses not only to sediment but also to other differing hydrographical features. In both cases though control of species distribution is enforced via rejection ability and colony morphology. Rate and persistancy of sediment settlement is important.

The stability of patches of soft substrate affects the sediment load falling on adjacent reef corals. Sediment resuspension by soft substrate infauna led to a reduction in growth of Montastrea annularis in Jamacia by up to $50 \%$ (Aller and Dodge, 1974; Dodge et al., 1974). Sediment produced by dredging in Bermuda (Dodge and Vaisnys, 1977) and Curaçao (Bak, 1978) inflicted differential effects on coral survival, favouring those able to reject sediment, but reducing growth and life spans of survivors.

\section{Water Movement}

Both currents and wave action have profound influence on reef distribution, and on any one reef slope both affect coral zonation and distribution patterns (e. g. Geister, 1977; for a detailed, general review on water-movement consult 'Marine Ecology': Vol. I: Riedl, $1971 \mathrm{a}, \mathrm{b})$. The force of water movement is invariably greatest in the region of breaking water but may rarely decline uniformly with depth. On one fringing reef (Roberts et al., 1975) wave force declined with depth, but force attributed to current increased to $36 \mathrm{~m}$ or more. The sum of both provided a bimodal pattern with a minimum at about $10 \mathrm{~m}$.

Ultimately, the physiological and structural tolerances to water movement of each species bear strongly on its observed distribution. Three species from different water movement regimes removed to tanks grew and reproduced best under those same conditions or benefited from more vigorous movement up to fairly severe levels (Jokiel, 1978). When grown under much less severe conditions than normal, Pocillopora meandrina ceased growth. Surface topography of the corals and its effect on the boundary layer appeared to be important, since faster water movement appears to aid exchange of solutes required for, or produced by, coral metabolism.

Strong currents cause coral polyps to retract. Hubbard (1974) directed currents at several Caribbean corals, noting the velocity required to produce a polyp response, the delay before response and the recovery period. Her view was that rapid recuperation rates following polyp contraction were important. She concluded that one vital effect of high current was restriction of the polyp's feeding ability, and that their primary requisite was to capture food rather than escape damage. Where rapid-response and current-tolerant species such as Montastrea spp. thrive in high current areas, they significantly alter bottom topography, thus providing sheltered areas for other species. Consequently, a succession related to differential polyp responses to currents was postulated.

Better known is the exclusion by water movement of fragile skeletal morphólogies, leading to zonation of species or fragile ecomorphs of species with high skeletal plasticity. The range of water movementrelated skeletal shape within some species is clearly evident from taxonomic works, (e. g. Pocilloporidae: Veron and Pichon, 1976, and Acropora: Wallace, 1978). Although ramose forms may thicken with increasing turbulence, most reach their limit of adaptation below the maximum levels of wave turbulence. Thus, mechanical studies of the drag required to break the large, tabular Acropora reticulata for example, showed that its absence above $7.7 \mathrm{~m}$ on windward reefs of Enewetak could be explained solely by wave energy (Vosburgh, 1977).

Strength alone inadequately explains zonation related to water movement for many species. Slow water flow through a branching colony may be fairly uniform and horizontal, but in faster water flow it may be deflected diagonally outwards by a 'stagnant' region within the colony (Chamberlain and Graus, 1975). These authors postulate a maximum interior flow rate for all colonies, which represents optimum velocity, 
and which should influence their favoured hydrodynamic conditions on the reef. In very strong water movement, calculation from hydrodynamic theory (Graus et al., 1977) suggests 2 adaptive strategies: a reduction to massive and encrusting forms, or an orientation of branches into the waves. Acropora palmata demonstrates the latter well. Branch inclination changes with increasing water movement, with colony shape becoming more eccentric as branches orientate into the direction of oncoming waves. In this way $A$. palmata withstands high energy conditions. It is a major framebuilder in shallow water in the Atlantic region and the orientation adopted by the species increases limestone deposition and reef building in the manner shown by Shinn (1963) described under 'Reef Slope Structure and Coral Framework' (p. 84).

Coral zonation in extreme turbulence is described under the subheading 'Shallow Reef Slope'. In most cases the dominant control is assumed to be water movement, often turbulent or bi-directional. But even relatively slow current reveals marked effects on coral distribution and even reef morphology. In Anegada, 40 patch reefs are subjected to constant current of velocity $20 \mathrm{~cm} \mathrm{~s}^{-1}$. The patch reefs themselves showed orientation and elongation into the current, except when sheltered by others (Brown and Dunne, 1980). Two major reef building species, Acropora palmata and Montastrea annularis, exhibited marked distribution patterns on each of the 3 designated types of patch reef. Because all patch reefs were at fairly similar depths, light effects were not considered to be differentiating. The slow current and its clearly highlighted interrelationship with sediment represented the prime control.

Sedimentation, water movement and light are of similar importance to other sessile groups, including Millepora and other hydroids (Mergner, 1972, 1977), and sponges (Rutzler, 1972; Vacelet and Vasseur, 1977).

\section{Control by Temperature}

The limitation of reefs and hermatypic coral growth to seas with warm and fairly narrowly circumscribed surface temperatures is well documented (Wells, 1956 , 1957). Possibly the widest range is found near Oman where temperatures range from $16^{\circ}-40^{\circ} \mathrm{C}$ (Kinsman, 1964). However, this is exceptional, and low temperature is one cause of reduced diversity in marginal coral areas (Veron, 1974). Most work on temperature stems from reef flats where very high temperatures periodically result at low tides, or concerns growth (Buddemeier and Kinzie, 1976). Thermal tolerances, and temperatures of optimum growth, respiration and photosynthesis of corals vary between reefs, generally matching their natural ambient temperatures (Clausen and Roth, 1975; Coles et al., 1976; Coles and Jokiel, 1977). A rise of 2-4 $C^{\circ}$ may cause tissue damage, of 4-5 $\mathrm{C}^{\circ}$ death (Jokiel and Coles, 1974). Per $\mathrm{C}^{\circ}$, lower temperatures may be still more disadvantageous than raised temperatures (Jokiel and Coles, 1977). Further, temperature tolerance may be lowered if other environmental conditions are sub-optimal (Coles and Jokiel, 1978).

As some corals show differing growth rates dependent on temperature while others do not (Gladfelter et al., 1978) a potential exists for temperature to influence distribution within a reef. However, the influence of temperature is much more strongly mediated via reproductive rate. In Pocillopora damicornis reproductive and growth optima coincide at $26^{\circ}-27^{\circ} \mathrm{C}$, but reproduction is much more severely curtailed than growth outside this optimum range (Jokiel and Guinther, 1978). This species is the main reef builder in the Pacific reefs of Panama, where reef distribution and coral growth vary markedly with thermal conditions dictated by the influence of upwelling currents and with cloud cover (Glynn and Stewart, 1973; Glynn, 1977). The former argue that the distribution of these reefs may be mediated more by an inability to compete with other benthic species at lower temperatures than by direct debilitating effects of temperature on reproduction. For a general review regarding temperature effects on marine invertebrates consult 'Marine Ecology', Vol. I: Kinne (1970).

\section{Control by Predation}

While early studies suggested that corals suffered little predation, lately some more significant corallivores have come to light (Robertson, 1970; Randall, 1974: Bruce, 1976; Patton, 1976). Additionally, disturbance effects by grazers and by predators have marked consequences on the ratios of coral species, their spatial distribution and zonation.

Glynn (1973a) lists 5 Caribbean invertebrate corallivores, 1 polychaete, 1 decapod and 3 molluscs. To this may be added the locally significant facultative coralivore Diadema (Bak and van Eys, 1975). Of the others mentioned, the polychaete Hermodice may kill $3 \mathrm{~cm}^{2}$ in $3 \mathrm{~h}$, existing in low densities of less than $1 \mathrm{~m}^{-2}$, while the gastropod Coralliophila may consume $9 \mathrm{~cm}^{2} \mathrm{~d}^{-1}$ each, living in mean densities of $13 \mathrm{~m}^{-2}$ (Ott and Lewis, 1972). The main invertebrate Indo-Pacific predator, Acanthaster is discussed, briefly, later. Others include the gastropod Jenneria which destroyed $0.8 \mathrm{~g} \mathrm{~d}^{-1}$ (of which $3.7 \%$ was organic) in eastern Pacific reefs, where hermit crabs Trizopagurus and Aniculus were also significant though smaller predators (Glynn et al., 1972). 
Selectivity for certain coral species is evident in several of the above predators. Some Chaetodontidae show preference when presented with different coral species (Reese, 1977), while Acanthaster chose Montipora verrucosa where the coral occupied $5 \%$ of the substrate, ignoring the $90 \%$ cover by Porites compressa (Branham et al., 1971).

Effects on coral populations by predators and grazers are complex, acting more often indirectly at second order level or further rather than directly.

The invertebrate group with the most studied effect on the coral community are echinoderms. Diadema prevents space monopolisation by algae in both Eilat (Benayahu and Loya, 1977b) and the Caribbean (Lewis, 1964; Sammarco et al., 1974). Three other grazing echinoids on shallow Red Sea reef slopes are important in releasing substrate for coral settlement (Dart, 1972). Here, the echinoid distribution is itself probably a result of algal crop levels. However, echinoid grazing effects are more complex than simple release of substrate from algal dominance. While Diadema removes algae, its rasping causes substrate abrasion and damage to juvenile corals (Sammarco, 1980). Hence, although algae increased when Diadema was removed from experimental plots, initial coral settlement also increased. Following this primary succession event, however, the coral spat suffered large mortality from the more rapidly growing algae. For optimum coral survival under postprimary succession conditions, Sammarco (1980) found that a moderate number of urchins $\left(4-16 \mathrm{~m}^{-2}\right)$ was required, with this depending on coral species also.

The effects of urchin feeding on total reef production and extent can be considerable. The urchin Eucidaris feeds on Pocillopora in Galapagos, whose productivity is reduced in extreme cases to nil. Since this is the main framework species the lateral and vertical expansion of this reef is reduced considerably compared to reefs of nearby Panama where the urchins suffer greater predation from fish (Glynn et al., 1979).

The notorious corallivorous asteroid Acanthaster planci has been widely studied, both in low density and plague conditions (Endean, 1973). Each adult may kill 5-12 $\mathrm{m}^{2} \mathrm{y}^{-1}$. Further studies have indicated possible community effects on corals resulting from this predator. Where high Acanthaster numbers existed on eastern Pacific reefs the latter had high coral diversity and low $(43 \%$ ) cover. Where low Acanthaster numbers existed, reefs had low diversity and high ( $85 \%$ ) cover. Porter (1972b) suggested that by feeding on Pocillopora - the dominant genus - the asteroid was increasing recruitment and growth possiblities of other corals. However, in the same region Glynn (1973d, 1974b) found that Pocillopora was preyed upon less than expected on an abundance basis, and that Acanthaster selectively destroyed rare corals. He did not find the same relationship with diversity. Glynn $(1976,1980)$ described one reason why this formidable starfish avoids Pocillopora: the coral contains a commensal crab which nips the tube feet of Acanthaster and thus repels it. Not only is Pocillopora protected, but massive forms surrounded by it are also shielded while others, unprotected, are destroyed.

According to Endean (1974), Acanthaster predation is often nonspecific, with coral mortality related to sea star density only. Then, only shallow corals in turbulent water may escape a major plague. In other cases differential effects have been noted which may alter coral distribution patterns. Invasions of adults may commence in deeper water while juveniles invade shallow areas first (Endean and Stablum, 1973; Endean, 1974). Even in devastated areas several corals may be left ${ }_{i}$ these include Stylophora, Pocillopora, massive forms with apparently easy access such as Porites, Astreopora, Platygyra, and the stinging Millepora (Endean, 1973; Nishihira and Yamazato, 1974). Survivors may subsequently become relatively abundant - Millepora communities have been assumed to result from this. Algae and alcyonarian colonisation has also been noted.

The depths at which fish are reported to have most effect on corals may be limited to shallow water above $10 \mathrm{~m}$ (Bakus, 1969, 1972) but other studies revealed significant grazing to at least $65 \mathrm{~m}$ (Van den Hoek et al., 1978). In Guam, Neudecker $(1977,1979)$ transplanted Pocillopora damicornis from $1.3 \mathrm{~m}$ to 15 and $30 \mathrm{~m}$ where they were heavily predated, though not killed. The coral did not occur naturally at these depths. Its growth there was rapid if protected by fish exclusion cages, but otherwise fish selected this species preferentially, distinguishing it even from others of the same genus. A control over the coral's depth distribution by fish was strongly suggested.

Scaridae are the main group of fish to eat, disturb and modify coral populations (Bakus, 1966, 1972). Effects of scarid rasping include modification of colony shape in the massive Montastrea annularis, and fragmentation of ramose species causing recession of their growth (Frydl, 1979). Low intensities of parrot fish grazing lead to a reef community dominated by fleshy algae; at intermediate intensities a greater diversity of corals may occur, while at very high levels coral diversity and biomass decline again (Brock, 1979). Thus, as with Diadema grazing, an optimum level of parrot fish grazing for coral populations exists, one which corresponds roughly to actual levels on many reefs. Since cryptic regions of reef are less accessible to scarids the existence of small refuges and even larger caves within the reef are also important, (Day, 1977; Brock, 1979). 
Small pomacentrid fish with strong territorial sense tend to repel intruders from their territories. Their exclusion of herbivores has a marked effect, causing thick algal mat development which hinders coral growth and diversity (Vine, 1974; Kaufman, 1977; Potts, 1977). It also retards coralline algal growth, reducing substrate cementation (John and Pople, 1973).

Thus feeding by some grazers and predators leads to selective settlement of corals in some cases (Vine, 1974), while increasing coral success generally when coral competitors are consumed (Birkeland, 1977).

\section{Control by Interspecific Competition}

\section{Mechanisms in Corals}

Active competition between coral tissues may influence survival at individual and species levels and lead to community effects.

The best known method occurs when mesenteric filaments are extruded through the polyp wall onto the target coral (Fig. 4a). This may form an important part of the nutrition of some species (Goreau et al., 1971), but Lang (1973) illustrated how digestion of competitors by this means provided Atlantic corals with an ecological benefit as well. She observed the number of subordinate species that each coral digested and obtained a roughly linear hierarchy in which most aggression was shown by small, slow-growing forms. In the Eastern Pacific however the dominant, fast growing Pocillopora showed similarly high aggression (Glynn et al., 1972) It seemed that evolution of fast growth and interspecific aggression of this sort had apparently developed in the same species in the Pacific but separately in the Atlantic (Porter, 1974b).

In the Indian Ocean, Sheppard (1979) categorised 30 common species as dominant, intermediate or subordinate from observations of undisturbed corals on reef slopes. Much less uniformity within a family or even genus appeared than had in the Atlantic. Families with aggressive Altantic members were generally less dominant in the Indian Ocean, being displaced by genera which are absent from the Atlantic. It was confirmed that several species showed both rapid growth and aggression, forming dense, sometimes monospecific zones, with abundance sometimes positively correlated to dominance. In these observations, however, usually only the result of a past conflict and not the mechanism by which it occurred was recorded.

Action by 'sweeper tentacles', occasional elongated tentacles with a large acrosphere (Den Hartog, 1977), is another component of the interspecific aggression complex (Fig. 4b). In the Caribbean, Richardson et al.
(1979) showed that such tentacles extended by Montastrea cavernosa held at bay its congener $M$. annularis which is dominant in terms of mesenteric filament digestion. Such tentacles now appear to exist in many coral species including several shown to be dominant in interspecific conflicts on the reef (Wellington, 1980; own observation) and may be one cause of apparent reversals of dominance

Although true tentacles, the sweepers appear to be functionally analogous to acrorhagi and catch tentacles in some aggressive anemones (Francis, 1973; Purcell, 1977). Functionally similar in some instances are the entire, long polyps of Goniopora spp. Although their tentacles are relatively tiny these 'sweeper polyps' have been observed to cause the death of another species within their sweep (Fig. 4c). Their mechanism of action - nematocyst, digestive or simple abrasion - remains unknown.

Immunological responses between species and between different colonies of the same species could provide a futher component of the aggression complex when coral tissues contact (Hildemann et al., 1977 a, b). With intergeneric contacts, cytotoxic damage or death was usually sustained by the tissue of one side only, which is a feature of the other forms of aggression. However, contacts between different species of one genus and different colonies of one species showed bilateral bleaching and damage. There is currently no indication of what the hierarchy or ecological importance is, except that Fungia scutaria appeared to be dominant in numerous contacts (Hildemann et al., 1977 b) and Fungia was dominant in most conflicts on reef slopes of Chagos (Sheppard, 1979).

Chemoreception by the aggressor of the presence of the subordinate is a likely prerequisite. Corals have sensitive receptive mechanisms, with concentrations of some amino acids as low as $10^{-7}$ or $10^{-9}$ inducing feeding responses, including filament extrusion, in several species (Mariscal and Lenhoff, 1968; Goreau et al., 1971; Lehman and Porter, 1973; Muscatine, 1973). The causative basis of the mesenterial filament controlled hierarchy is not the mere efficiency in extruding such structures - most species kill some others in this way - but may depend on chemoreceptive sensitivity or specificity by the dominant (Sheppard, 1979) or on the extent to which each species chemically signals its presence. The underlying basis of this and the other mechanisms remains unexplained. The response is assumed to be mainly interspecific. It was used to separate species of Scolymia (Lang, 1971) and Acropora (Potts, 1978). However, it occurs between phenotypically different forms of Montastrea annularis (Dustan, pers. comm. in Lang, 1973) and amongst $A$. palifera (Potts, 1976), so this activity need not indicate a difference of species. 

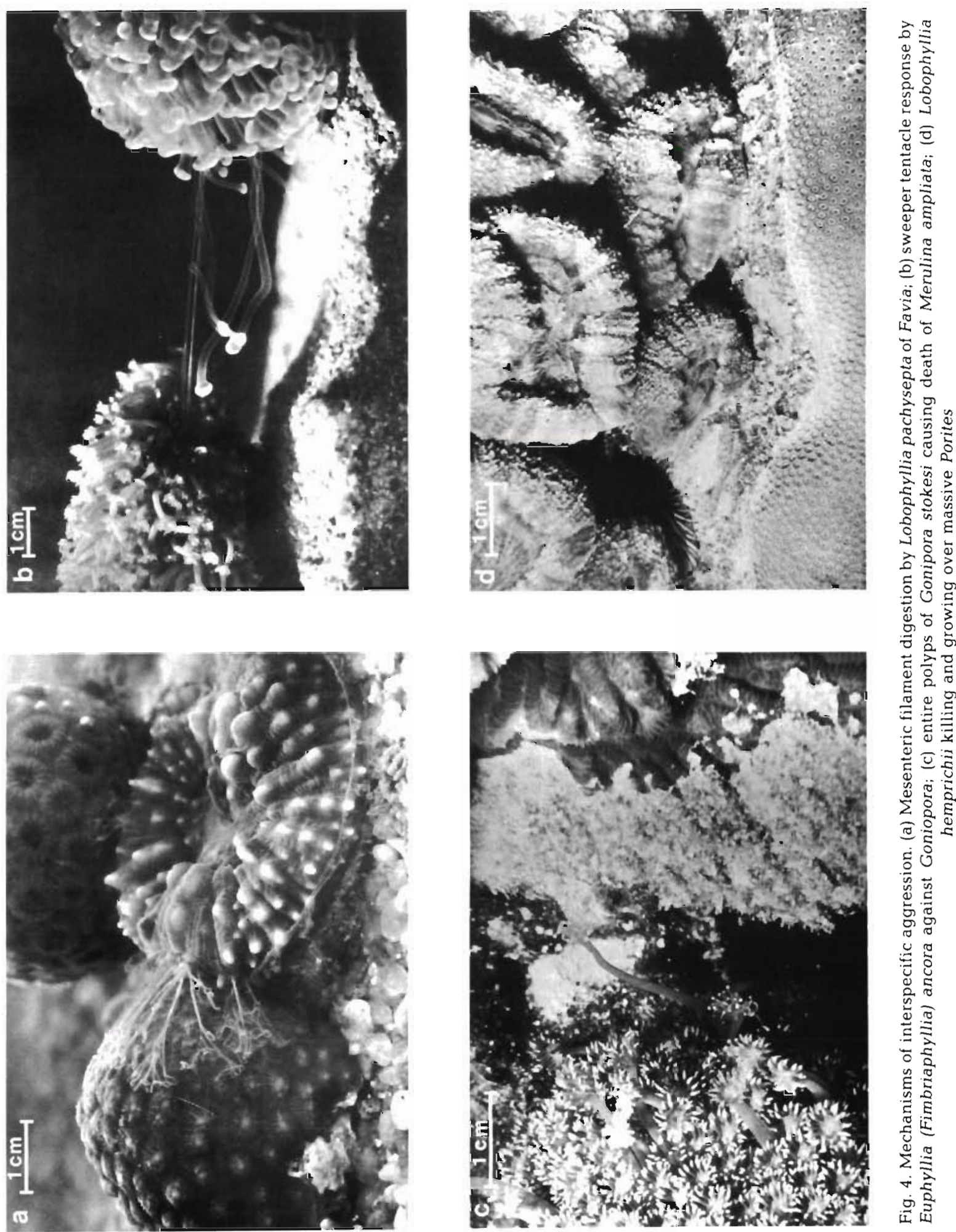

4. म4 
Thus at least 3 or 4 physiological mechanisms are part of the aggression complex. Each may produce a hierarchy of sorts, but their combination results in a complicated situation where presently unpredictable events and apparent reversals of dominance may occur.

There is no reason to suppose that hierarchies will be the same on widely separated Indo-Pacific reefs. For example, Loya (1976d) lists several species which dominate Stylophora pistillata at Eilat, some of which are subordinate to it in Chagos and Eastern Australia (Sheppard 1979; unpubl.). Coral diversity at these 3 sites varies 4 -fold, so competition intensity itself is probably different. This can only be resolved with data from several sites.

Some discussion has centred on whether each is a feeding, defensive or aggressive activity (e.g. Connell, 1976). Although sometimes a problem only of semantics, Lang (1980) has partially reconciled the different views. The action of filaments may provide nourishment. Equally it prevents encroachment onto its space, and precedes the encroachment of the dominant over the killed skeleton of the subordinate (Figure $4 \mathrm{~d}$ ). Sweeper tentacles and polyps have an undisclosed role in nutrition but a confirmed one in space maintenance. Although in a particular conflict the role of a mechanism may be clear, in general these cannot be clearly labelled. Connell (1976) grouped the sum of these effects as 'direct interactions' when they result from tissue contact and 'indirect interactions' for overgrowth without contact. Connell includes shading by Acropora tables in the latter; however analysis of the coral composition beneath Acropora tables at $10 \mathrm{~m}$ revealed no impairment (Sheppard, 1981d). Shading of this nature at this depth did not disadvantage other corals and was not regarded as a form of competition analogous to those mentioned above. The importance of shading in extremely shallow or deep areas has yet to be quantified.

\section{Other Benthic Groups}

The stony octocorals Heliopora coerulea and Tubipora musica have not been studied to any extent in this context, though brief observations (Sheppard, 1979) suggest they lack appreciable interactive ability of the kind described for scleractinians. In Chagos, this author found no evidence of these mechanisms in alcyonarians, although on the Great Barrier Reef many members of this group, which contain toxic chemicals (Bakus, 1981), show evidence of aggression by toxin secretion (Coll, pers. comm.). Aggression in anemones was shown by Sebens (1976) to parallel substrate persistence: those on massive corals actively destroyed the coral, those on dead coral, rubble or sand were aggressive towards other anemones competing with them for space, while those on fragile corals were not aggressive. A high order of spatial partitioning was demonstrated and related to their aggression. Most work on coelenterate interactions and their effect on community structure however is from cooler water (Francis, 1973, 1976; Bigger, 1976, 1980; Purcell, 1977; Brace and Pavey, 1978).

Some ectoprocts show interspecific competition by generation of microcurrents which deprive faster growing neighbours of food (Buss, 1980a, b). Significantly, size or age of the colony strongly influenced competitive ability, which does not seem to be the case with corals. Ascidians (Stoecker, 1980) and sponges (Baslow, 1969; Burkholder, 1973) produce toxins and appear to use allelochemicals in expansive and defensive ways. The sponge Siphonodicton appears to inhibit growth of the coral Montastrea cavernosa (Jackson and Buss, 1975), possibly reducing dispersion of the toxin by concentrating it in mucus. In Guam, Bryan (1973) noted that the sponge Terpios sp. could kill a wide range of corals. It overgrew them without regard to polyp size or nematocyst toxicity at about $23 \mathrm{~mm}$ month $^{-1}$; this was significantly faster than over dead substrate, possibly due to a nutritive advantage gained from absorbing the coral tissue.

In a very few cases initial contacts which lead to competitive interactions are not entirely fortuitous. In the Caribbean, Millepora directs growth specifically towards target gorgonians which are suitable as substrate (Wahle, 1980). The essential part of initial chemoreception of the target was illustrated by the necessity for Millepora to live down-current of the gorgonian. This is neither a device to randomly search for new substrate, nor a general response to any nearby object; rather it is a specific response to living gorgonians'. The enhanced growth of the sponge Terpios over living coral (Bryan, 1973) presumably also leads to a measure of directed growth. Such effects have yet to be recorded in corals. As pointed out by Wahle (1980) the boundaries of potential targets thus extend considerably beyond their physical limits.

Antibiotic and antifouling effects are widespread and clearly vital to survival in the species concerned (Burkholder, 1973). Chemical defense by benthic reef species is likewise widespread (Cameron, 1974; Bakus, 1981).

\section{Intraspecific Competition}

Although substrate cover on most reef slopes by corals is commonly $50-75 \%$ or more, usually the communities concerned are diverse. Occasionally a single species occurs largely alone. 
Examples occur in areas of low environmental predictability or on new substrate, commonly on introduced structures or on reef flats whose communities suffer periodic mortality (Loya, 1976b). Stylophora pistillata is one opportunistic species in the Red Sea which can reach densities of $60 \mathrm{~m}^{-2}$ (Loya, 1976c). Porites furcata similarly monopolises some Caribbean reef flats where several colonies totalled over $12 \mathrm{~kg} \mathrm{~m}^{-2}$ (Glynn, 1973a). On Pacific Panama coasts Pocillopora spp. grow in densities of $40 \mathrm{~m}^{-2}$ (Glynn et al., 1972). In no instance was intraspecific competition reported. The life strategy of some of these species is one of rapid colonisation and high mortality especially with young colonies (Loya, 1976c, d); self-inhibition, in other words, is not of immediate importance in securing new substrate.

In several deeper and diverse areas in Chagos some dominant, ramose or foliose species formed nearly unbroken canopies (Sheppard, 1980a). Their size/frequency relationships showed bimodal patterns (Fig. 5). Small colonies present in large numbers (first mode) remained small until a gap in the canopy permitted a rapid expansion across to the canopy or adult (second) mode. This was interpreted as intraspecific competition amongst the dominant canopy. Its apparent effect was to extend the zone of dense cover by the species to the limits at which it could live (Sheppard, 1981c). This expansive pressure came about because, although within the zone growth of individuals was delayed, young colonies settling at the edge and outside the zone were not restricted and retained a capacity for interspecific aggression. The result was that the zone of dense cover by the species frequently coincided with their total distribution limits. These species showed characteristics of K-selection, another correlate of which is a high degree of stability.

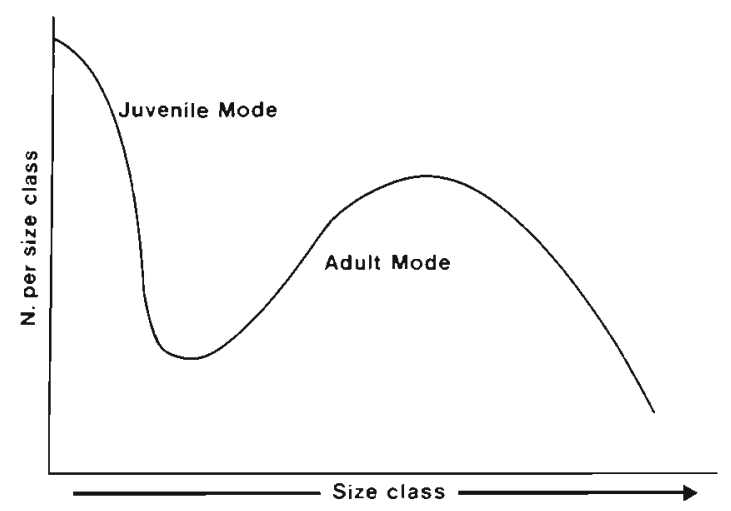

Fig. 5. Composite size-frequency distribution of 8 crowded coral populations exhibiting intraspecific competition (After Sheppard, 1980a)

\section{Ecological Effects of Intra- and Interspecific Interactions}

In the Atlantic Ocean, Lang (1973) found that the aggressive activity of mussids and faviids compensated for their slow growth so that they maintained a presence (albeit low) on reef slopes. In the Indo-Pacific Ocean, however, several main framework builders are amongst the highly aggressive species. These include Pocillopora damicornis (Glynn et al., 1972; Wellington, 1980), Acropora hyacinthus, A. palifera and, in deeper areas, Galaxea astreata (Sheppard, 1979). However, although it is likely that aggression influences the densities of each species and affects survival in individual colonies, evidence of its role in community dynamics is scarce. An example comes from the shallow, high energy groove and spur region in Chagos (see 'Coral Distributions'). Two coral communities exist here: one overwhelmingly dominated by the very aggressive $A$. palifera, and a more diverse community which entirely lacks this species. The species lives in a narrow environmental 'window', only surviving in shallow, turbulent water, but not the most turbulent. Where it can live, it overwhelms. Thus, wave energy appears to control whether or not the species could live; if it can, then the coral controls the community structure and diversity (Sheppard, 1979, 1981b). The higher coral diversity which occurs when A. palifera is absent consists of less aggressive species; this implicates the aggression of $A$. palifera in its success.

For the Atlantic reefs of Bonaire, Scatterday (1977) showed a similar effect. In shallow but continuously submerged areas, the aggressive Monastrea annularis dominated. However, this species is sensitive to desiccation and was selected against in reef communities subjected to periodic emergence. Such communities exhibited increased diversity. Scatterday (1977) argued that this was a result of selective elimination of this superior competitor. He contrasted the different nature and severity of emergence on this reef to that experienced on Red Sea reefs, where Fishelson (1973) had attributed high diversity to space creation. In this example also, aggression of one species is implicated in community determination.

Theoretical interest in interactions centres on their roles in maintaining diversity in the reef ecosystem and on how competitors with different hierarchical status may coexist. In at least some ways a low ranked competitor must gain advantage over its 'superior' or be excluded.

Fig. 6a-f summarises cited interaction events in coral or other coral reef invertebrates where counterbalancing factors are mentioned. Both transitive and intransitive mechanisms (Buss, 1980b) are shown. The former are most numerous, and several counterbalanc- 

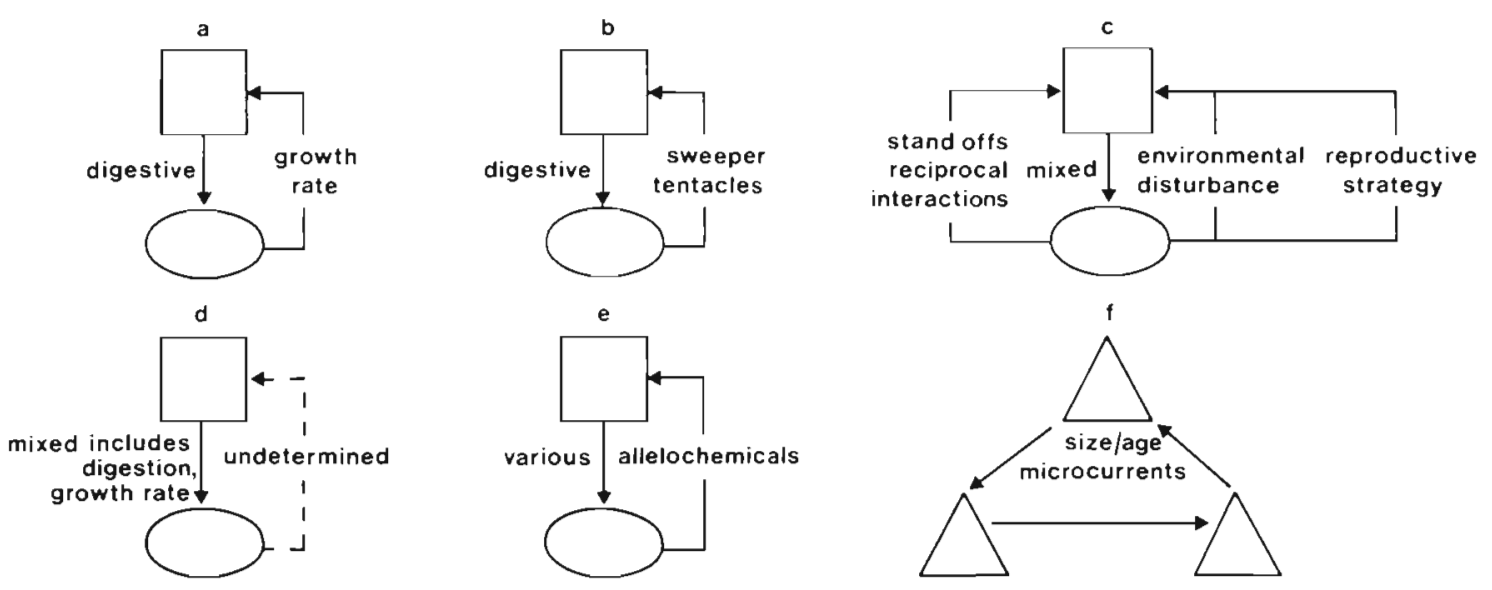

Fig. 6. Schematic summary of cited interaction mechanisms and counterbalancing mechanisms. Boxes: dominant; circles: subordinate species in the principal (for this purpose) hierarchy. Triangles: species in 'intransitive' or 'network' situations. Sources: (a) Lang (1973), (b) Richardson et al. (1979), (c) Connell (1976), (d) Glynn et al. (1972); Sheppard (1979), (e) Jackson and Buss (1975), (f) Buss and Jackson. (1979), Buss (1980a, b)

ing effects have been proposed or demonstrated. In the transitive digestive hierarchies amongst Atlantic corals 2 factors have been suggested to balance the feature focused upon: the faster growth rate of species lower in the hierarchy and sweeper tentacles (Fig. $6 \mathrm{a}, \mathrm{b})$. On reef flats in the Indo-Pacific Ocean, Connell (1976) remarks on several factors offsetting the dominance of highly ranked species (Fig. 6c). In deeper Indo-Pacific waters the offsetting factors were undetermined. In these, the mechanisms forming the partially transitive hierarchy include fast growth which distinguishes it from the situation in the Atlantic Ocean mentioned above (Fig. 6d). Fig. 6 (e) illustrates the counterbalance given by toxins in sponge-invertebrate (including corals) interactions.

Competitive networks which involve the occurrence of a loop in an otherwise hierarchical sequence' (Buss and Jackson, 1979) describe the instances of perfect intransitivity found for triplets of ectoprocts and of 2 corals and 1 ectoproct (Fig. 6f). For the term 'network' to be useful it should refer only to cases where the mechanism of competition is the same between each of the 3 (or any number of) competitors, for all the balances shown in Fig. 6a-e provide loops in the total pattern.

For coexistence to occur there must clearly be sufficient counterbalance to any perceived hierarchy to prevent a total space occupation by a single species, though the latter does occasionally occur over limited reef areas. Future lines of research must be (a) to elucidate other mechanisms involved, some of which have been suggested but unproven, and (b) to determine exactly how these mechanisms regulate the community structure, and the extent to which they do this relative to the physical controls.

\section{CONCLUSIONS}

The mechanisms by which some environmental factors influence coral populations remain a central problem in coral population ecology. Control of distribution may be mediated most simply through limits on the skeletal structure; foliose and some ramose shapes are most susceptible to breakage in severe water movement for example. This may limit some species but is exploited by others. But in many cases control over the presence or absence of a species is mediated through complex physiological characteristics which either interact with the environment or which provide superior competitive ability. The former include active sediment rejection, development of morphology which controls water flow over tissue to facilitate solute exchange, and includes the entire range of larval selection patterns. Physiological mechanisms may also provide superior competitive ability in a given set of environmental controls, as well as mechanisms of defense from predation. It is suggested that these biological controls are more important in areas of reef slopes which lie well within environmental extremes. If environmental conditions are not extreme and are even benign, there is less reason for them to be regarded as exerting much control. Such conditions occur over a very large part, perhaps most, of the average reef slope, and biological controls have been observed in extreme areas as well. Their importance is, so far, difficult to quantify, though evidence is increasing to suggest such factors are as important as the 'traditional' physical environmental controls.

It has long been suggested that the environmental factors of wave energy, light, temperature and sediment are the main 'forcing functions' of coral distribu- 
tion, while physiological characteristics merely represent adaptations to them. This view is now too simplistic for many situations on the reef slope where physical factors are neither extreme nor limiting. Where a population structure is immediately controlled by, for example, the aggression of the dominant species, the latter is itself a major 'forcing function'. The addition of this factor, with those of predation and life strategy choice, to the traditional abiotic controls is one of the most important developments of coral population research in recent years. Their mechanisms remain poorly understood in many cases, but their essence and complexity have been demonstrated. Evidence about some controls (e. g. that exerted by particulate food supply), remains so limited in ecological terms that assessment of its efficacy remains almost impossible. Other such controls undoubtedly remain undetected; for example, competitive effects which do not result in tissue death would appear to be likely.

Recent work amply confirms the significance of the long recognised abiotic controls discussed here. Quantification of their effects remains complicated by the lack of linearity between the gradients of the factors concerned and the behaviour of the responding species or population. The decrease of light with depth, for example, is a simple curve, but the utilization of that light by many species, and the response of the population as a whole is not correlated to it. Whereas nonlinearity itself may be adjusted for, the controls interact with each other as well which tends to obscure, in several studies, exactly which is the primary control of the coral population in a set of circumstances. The ways in which the effects of several of these are mediated through to the community however, is a second very important result of recent work.

While there is value in presenting only fundamental points in ecosystem models several investigators tend to present oversimplified pictures of coral populations. Factors previously overlooked may prove to be of great importance (e. g. the role of commensal crabs in Pocillopora reefs). Such observations do not, of course, reduce the importance of abiotic controls, but they do show new dimensions added to our knowledge of coral population control. Elucidation of these, and continuing re-examination of assumed degrees of importance, offer profitable lines for future research.

Acknowledgements. I am most grateful to Drs. J. Bunt, B. Chalker, Z. D. Dinesen, T. Done and J. E. N. Veron for their very helpful discussions and for reading and suggesting improvements to the manuscript. For help in locating literature I am grateful to Anne Sheppard.

\section{LITERATURE CITED}

Adey, W. H. (1975). The algal ridges and coral reefs of St. Croix, their structure and Holocene development. Atoll. Res. Bull. 187: 1-67

Adey, W. H., Adey, P. J., Burke, R., Kaufmann, L. (1977). The Holocene reef systems of eastern Martinique, French West Indies. Atoll. Res. Bull 218: 1-40

Adey, W. H., Burke, R. B. (1977). Holocene bioherms of Lesser Antilles - geologic control of development. In: Frost, S. H., Weiss, M. P., Saunders, J. B. (eds.) Reefs and related carbonates. Am. Ass. Petr. Geol. Tusla, Oklahoma, pp. $67-81$

Adey, W. H., Macintyre, I. (1973). Crustose coralline algae: a re-evaluation in the geological sciences. Geol. Soc. Am. Bull. 84: 883-904

Alldredge, A. L., King, J. M. (1977). Distribution, abundance, and substrate preferences of demersal reef zooplankton at Lizard Island lagoon, Great Barrier Reef. Mar. Biol. 41: 317-333

Aller, R. C., Dodge, R. E. (1974). Animal-sediment relations in a tropical lagoon, Discovery Bay, Jamaica. J. mar. Res. 32: 209-232

Antonius, A. (1980). Occurence and distribution of stony corals in the Gulf of Cariaco, Venezuela. Int. Revue ges. Hydrobiol. 65: 321-338

Bak, R. P. M. (1975). Ecological aspects of the distribution of reef corals in the Netherlands Antilles. Bidjr. Dierk. 45: 181-190

Bak, R. P. M. (1976). The growth of coral colonies and the importance of crustose coralline algae and burrowing sponges in relation with carbonate accumulation. Neth. J. Sea Res. 10: 285-337

Bak, R. P. M. (1977). Coral reefs and their zonation in Netherlands Antilles. In: Frost, S. H., Weiss, M. P., Saunders, J, B. (eds.) Reefs and related carbonates - ecology and sedimentology. Am. Ass. Petr. Geol., Tulsa, Oklahoma, pp. 3-16

Bak, R. P. M. (1978). Lethal and sublethal effects of dredging on reef corals. Mar. Pollut. Bull. 9: 14-16

Bak, R. P. M., Brouns, J. J. W. M., Heys, F. M. L. (1977). Regeneration and aspects of spatial competition in the scleractinian corals Agaricia agaricites and Montastrea annularis. Proc. 3rd Int. Symp. Coral Reefs, Miami 1: 143-148

Bak, R. P. M., Engel, M. S. (1979). Distribution, abundance and survival of juvenile hermatypic corals (Scleractinia) and the importance of life history strategies in the parent coral community. Mar. Biol. 54: 341-352

Bak, R. P. M., Luckhurst, B. E. (1980). Constancy and change in coral reef habitats along depth gradients at Curaçao. Oecologia (Berl.) 47: 145-155

Bak, R. P. M., Steward-Van Es, Y. (1980). Regeneration of superficial damage in the Scleractinian corals Agaricia agaricites F. pururea and Porites astreoides. Bull. mar. Sci. 30: 883-887

Bak, R. P. M., van Eys, G. (1975). Predation of the sea urchin Diadema antillarum Philippi on living coral. Oecologia (Berl.) 20: 111-115

Bakus, G. J. (1966). Some relationships of fishes to benthic organisms on coral reefs. Nature, Lond, 210: 280-284

Bakus, G. J. (1968). Sedimentation and benthic invertebrates of Fanning Island, central Pacific. Mar. Geol. 6: 45-51

Bakus, G. J. (1969). Energetics and feeding in shallow marine waters. Int. Rev. Gen. Exp. Zool. 4: 275-369

Bakus, G. J. (1972). Effects of the feeding habits of coral reef fishes on the benthic biota. Proc. Symp. Corals, Coral Reefs (1969). J. mar. biol. Ass. India 1972: 445-448 
Bakus, G. J. (1975). Marine zonation and ecology of Cocos Island, off Central America. Atoll. Res. Bull. 179: 1-12

Bakus, G. J. (1981). Chemical defense mechanisms on the Great Barrier Reef, Australia. Science, N. Y 211:497-499

Barnes, D. J. (1973). Coral reef project - Papers in memory of Dr Thomas R. Goreau. 12. Growth in colonial scleract1nians. Bull mar Sci. 23: 280-298

Barnes, D. J., Taylor, D. L. (1973). In situ studies of calcification and photosynthetic carbon fixation in the coral Montastrea annularis. Helgolander wiss. Meeresunters. 24 $284-291$

Barnes, J., Bellamy, D. J., Jones, D. J., Whitton, B. A., Drew, E. A., Lythgoe, J. (1970). Sublittoral reef phenomena of Aldabra. Nature, Lond. 225: 268-269

Barnes, J., Bellamy, D. J., Jones, D. J., Whitton, B. A., Drew, E. A., Kenyon, L., Lythgoe, J. N., Rosen, B. R. (1971). Morphology and ecology of the reef front of Aldabra. In: Stoddart, D. R., Yonge, C. M. (eds.) Regional variation in Indian Ocean coral reefs (Symp. zool. Soc. Lond. 28). Academic Press, London, pp. 87-114

Baslow, M. H. (1969). Marine pharmacology, Williams and Wilkins, Baltimore

Benayahu, Y., Loya, Y. (1977a). Space partitioning by stony corals, soft corals and benthic algae on the coral reefs of the northern Gulf of Eilat (Red Sea). Helgoländer wiss. Meeresunters. 30: 362-382

Benayahu, Y., Loya, Y. (1977b). Seasonal occurrence of benthic algae communities and grazing regulation by seaurchins at the coral reefs of Eilat, Red Sea. Proc. 3rd Int. Symp. Coral Reefs, Miami 1: 383-389

Bigger, C. H. (1976). The acrorhagial response in Anthopleura krebsi: intraspecific and interspecific recognition. In: Makie, G. O. (ed.) Coelenterate ecology and behaviour. Plenum Press, New York, pp. 127-136

Bigger, C. H. (1980). Interspecific and intraspecific acrorhagial aggressive behaviour among sea anemones: a recognition of self and not-self. Biol. Bull. mar biol. Lab., Woods Hole 159: 117-134

Birkeland, C. (1977). The importance of rate of biomass accumulation in early successional stages of benthic communities to the survival of coral recruits. Proc. 3rd Int. Symp. Coral Reefs, Miami 1: 15-21.

Bonem, R. M., Stanley, G. D. (1977). Zonation of a lagoonal patch reef: analysis, comparison, and implications for fossi] biohermal assemblages. Proc. 3rd Int. Symp. Coral Reefs, Miami 2: 175-181

Bouchon, C. (1981). Quantitative study of the scleractinian coral communities of a fringing reef of Reunion Island (Indian Ocean). Mar. Ecol. Prog. Ser. 4: 273-288

Brace, R. C., Pavey, J. (1978). Size dependent dominance heirarchy in the anemone Actinia equina. Nature, Lond. 273: $752-753$

Braithwaite, C. J. R. (1971). Seychelles reefs: structure and development. In: Stoddart, D. R., Yonge, C. M. (eds.) Regional variation in Indian Ocean coral reefs (Symp. zool. Soc. Lond. 28). Academic Press. London, pp. 39-63

Brakel, W. H. (1979). Small-scale spatial variation in light available to coral reef benthos: quantum irradiance measurements from a Jamaican reef. Bull. mar. Sci. 29: 406-413

Branham, J. M., Reed, S. A., Bailey, J. H., Caperon, J. (1971). Coral eating sea stars Acanthaster planci in Hawaii. Science, N. Y 172: 1155-1157

Bright, T J. (1977). Coral reefs, nepheloid layers, gas seeps and brine flows on hard-banks in the northwestern Gulf of Mexico. Proc. 3rd Int. Symp. Coral Reefs, Miami 1: 39-46

Brock, R. E. (1979). An experimental study on the effects of grazing by parrotfishes and role of refuges in benthic community structure. Mar. Biol. 51: 381-388

Brown, B. E., Dunne, R. P. (1980). Environmental controls of patch-reef growth and development. Mar. B1ol. 56: 85-96

Bruce, A. J. (1976). Shrimps and prawns of coral reefs, with special reference to commensalims. In: Jones, O. A., Endean, R. (eds.) Biology and geology of coral reefs, Vol. 3. Academic Press, London, pp. 37-94

Bryan, P. G. (1973). Growth rate, toxicity and distribution of the encrusting sponge Terpios sp. (Hadromerida: Suberitidde) in Ciuam, Marianas Islands. Micronesica 9: $237-242$

Buddemeier, R. W., Kinzie, R. A. (1976). Coral growth. Oceanogr Mar Biol. Ann. Rev. 14: 183-225

Burkholder, P. R. (1973). The ecology of marine antibiotics and coral reefs. In: Jones O. A., Endean, R. (eds.) Biology and geology of coral reefs, Vol. 2. Academic Press, London, pp. $117-182$

Buss, L. W (1979). Habitat selection, directional growth and spatial refuges: why colonial animals have more hiding places. In: Larwood, G., Rosen, B. R. (eds.) Biology and systematics of colonial organisms. Academic Press, London, pp. 459-497

Buss, L. W (1980a). Bryozoan overgrowth interactions - the interdependence of competition for space and food. Nature, Lond. 281: 475-477

Buss, L. W. (1980b). Competitive intransitivity and size-frequency distributions of interacting populations. Proc. natn. Acad. Sci. U.S.A. $77 \cdot 5355-5359$

Buss, L. W., Jackson, J. B. C. (1979). Competitive networks: nontransitive competitive relationships in cryptic coral reef environments. Am. Nat. 113: 223-234

Cameron, A. M. (1974). Toxicity phenomena in coral reef waters. Proc. 2nd Int. Symp. Coral Reefs, Brisbane 1: $513-518$

Chalker, B. E. (1976). Calcium transport during skeletogenisis in hermatypic corals. Comp. Biochem. Physiol. 54A: $455-459$

Chalker, B. E. (1977). Daily variation in the calcification capacity of Acropora cervicornis. Proc. 3rd Int. Symp. Coral Reefs, Miami 2: 417-423

Chalker, B. E., Taylor, D. L. (1975). Light-enhanced calcification and the role of oxidative phosphorylation in the coral Acropora cervicornis. Proc. R. Soc. Lond. B 190: 323-331

Chalker, B. E., Taylor, D. L. (1978). Rhythmic variations in calcification and photosynthesis associated with the coral Acropora cervicornis (Lamarck). Proc. R. Soc. Lond. B 201 : 179-189

Chamberlain, J. A., Graus, R. R. (1975). Waterflow and hydromechanical adaptions of branched reef corals. Bull. mar Sci. 25: 112-125

Chappell, J. (1980). Coral morphology, diversity and reef growth. Nature, Lond. 286: 249-252

Chuang, S. H. (1977). Ecology of Singapore and Malayan coral reefs - preliminary classification. Proc. 3rd Int. Symp. Coral Reefs, Miami 1: 55-61

Clausen, C. D., Roth, A. A. (1975). Effect of temperature and temperature adaptation on calcification rate in the hermatypic coral Pocillopora damicornis. Mar. Biol. 33: 93-100

Coles, S. L. (1969). Quantitative estimates of feeding and respiration for three scleractinian corals. Limnol. Oceanogr. 14: 949-953

Coles, S. L., Jokiel, P. L. (1977). Effects of temperature on photosynthesis and respiration in hermatypic corals. Mar. Biol. 43: 209-216

Coles, S. L., Jokiel, P. L. (1978). Synergistic effects of tempera- 
ture, salinity and light on the hermatypic coral Montipora verrucosa. Mar. Biol. 49: 187-195

Coles, S. L., Jokiel, P. L., Lewis, C. R. (1976). Thermal tolerance in tropical versus subtropical Pacific reef corals. Pacif. Sci. 30: 159-166

Colin, P. L. (1977). The reefs of Cocos-Keeling Atoll, eastern Indian Ocean. Proc. 3rd Int. Symp. Coral Reefs, Miami 1: 63-68

Colunga, L., Stone, R. (eds.) (1974). Proceedings of artificial reef conference, Texas A \& M University, Houston

Connell, J. H. (1973). Population ecology of reef building corals. In: Jones, O. A., Endian, R. (eds.) Biology and geology of coral reefs, Vol. 2, Biol. 1. Academic Press, London, pp. 205-245

Connell, J. H. (1976). Competitive interactions and the species diversity of corals. In: Mackie, G. O. (ed.) Coelenterate ecology and behaviour Plenum Press, New York, pp. $51-58$

Connell, J. H. (1978). Diversity in tropical rain forests and coral reefs. Science, N. Y 199: 1302-1310

Cribb, A. B. (1973). The algae of the Great Barrier Reef. In: Jones O. A., Endean, R. (eds.) Biology and geology of coral reefs, Vol. 2. Academic Press, London, pp. 47-75

Dahl, A. L. (1974). The structure and dynamics of benthic algae in the coral reef ecosystem. Proc. 2nd Int. Symp. Coral Reefs, Brisbane 1: 21-25

Dana, T F. (1976). Reef-coral dispersion patterns and environmental variables on a Caribbean coral reef. Bull. mar. Sci. 26: 1-13

Dana, T F. (1979). Species-numbers relationships in an assemblage of reef building corals: McKean Island, Phoenix Islands. Atoll. Res. Bull. 228: 1-27

Dart, J. K. G. (1972). Echinoids, algal lawn and coral recolonisation. Nature. Lond. 239: 50-51

Davies, P. S. (1977). Carbon budgets and vertical zonation of Atlantic reef corals. Proc. 3rd Int Symp. Reefs. Miami 1: 391-396

Davies, P. S. (1980). Respiration in some Atlantic reef corals in relation to vertical distribution and growth form. Biol. Bull. mar. biol. Lab., Woods Hole 158: 187-194

Davies, P. S., Stoddart, D. R., Sigee, D. C. (1971). Reef forms of Addu Atoll, Maldive Islands. In: Stoddart, D. R., Yonge, C. M. (eds.) Regional variation in Indian Ocean coral reefs (Symp. zool. Soc. Lond. 28). Academic Press, London, pp. $217-259$

Day, R. W. (1977). Two contrasting effects of predation on species richness in coral reef habitats. Mar Biol. 44: 1-5

D'Elia, C. F., Webb, K. L. (1977). The dissolved nitrogen flux of reef corals. Proc. 3rd Int. Symp. Coral Reefs, Miami 1: $325-330$

Den Hartog, J. C. (1977). The marginal tentacles of Rhodactis sanctithomae (Corallimorpharia) and the sweeper tentacles of Montastrea cavernosa (Scleractinia); their cnidom and possible function. Proc. 3rd Int. Symp. Coral Reefs, Miami 1: 463-469

Dinesen, Z. D. (1977). The coral fauna of the Chagos Archipelago. Proc. 3rd. Int. Symp. Coral Reefs, Miami 1: $155-161$

Dinesen, Z. D. (1980a). Some ecological aspects of coral assemblages in the Great Barrier Reef province. Ph. D. thesis, James Cook University of North Queensland, Australia

Dinesen, Z. D. (1980b). A revision of the coral genus Leptoseris (Scleractinia: Fungiina: Agariciidae). Mem. Qd Mus. 20: 181-235, pl. 1-16

Dodge, R. E., Aller, R. C., Thomson, J. (1974). Coral growth related to resuspension of bottom sediments. Nature Lond. 247: 574-577

Dodge, R. E., Vaisnys, J R. (1977). Coral populations and growth patterns: responses to sedimentation and turbidity associated with dredging. J. mar Res. 35: 715-730

Done, T. J. (1977). A comparison of units of cover in ecological classifications of coral communities. Proc. 3rd Int. Symp. Coral Reefs, Miami 1: 9-14

Done, T. J. (in press). Coral zonation: its nature and significance. In: Barnes, D. J. (ed.) Perspectives on coral reefs. Views arising from a workshop held at the Australian Institute of Marine Science, August 1979

Doty, M. S. (1974). Coral reef roles played by free-living algae. Proc. 2nd Int. Symp. Coral Reefs, Brisbane 1: 27-33

Drew, E. A. (1972). The biology and physiology of algainvertebrate symbiosis. II. The density of symbiotic algal cells in a number of hermatypic hard corals and alcyonarians from various depths. J. exp. mar. Biol. Ecol. 9: 71-75

Drew, E. A. (1973). The biology and physiology of alga. invertebrate symbioses. III. In situ measurements of photosynthesis and calcification in some hermatypic corals. J exp. mar. Biol. Ecol. 13: 165-179

Drew, E. A. (1977). A photographic survey down the seaward reef front of Aldabra. Atoll. Res. Bull. 193: 1-17

Dunne, R. P., Brown, B. E. (1979). Some aspects of the ecology of reefs surrounding Anegada, British Virgin Islands Atoll. Res. Bull. 236: 1-84

Dustan, P. (1975). Growth and form in the reef building coral Montastrea annularis. Mar. Biol. 33: 101-107

Dustan, P. (1979). Distribution of zooxanthellae and photosynthetic chloroplast pigments of the reef building coral Montastrea annularis Ellis and Solander in relation to depth on a West Indian coral reef. Bull. mar. Sci. 29: 79-95

Emery, A. R. (1968). Preliminary observations on coral reef plankton. Limnol. Oceanogr 13: 293-303

Emery, K., Tracy, J., Ladd, H. (1954). Geology of Bikini and nearby atolls. I. U. S. geol. surv. pap. 260A: 1-265

Endean, R. (1973). Population explosions of Acanthaster planci and associated destruction of hermatypic corals in the Indo-West Pacific region. In: Jones, O. A., Endean, R. (eds.) Biology and geology of coral reefs, Vol. 2. Academic Press, London, pp. 390-438

Endean, R. (1974). Acanthaster planci on the Great Barrier Reef. Proc. 2nd Int. Symp Coral Reefs, Brisbane 1: 563-576

Endean, R., Stablum, W. (1973). A study of some aspects of the crown-of-thorns starfish (Acanthaster planci) infestations of reefs of Australia's Great Barrier Reef. Atoll. Res. Bull. 167: 1-62

Falkowski, P. G., Dubinsky, Z. (1981). Light-shade adaptation of Stylophora pistillata, a hermatypic coral from the Gulf of Eilat. Nature, Lond. 269: 172-174

Faure, G. (1974). Morphology and bionomy of the coral reef discontinuities in Rodriguez Island. Proc. 2nd Int. Symp. Coral Reefs, Brisbane 2: 161-172

Fishelson, L. (1973). Ecological and biological phenomena influencing coral-species composition on the reef tables at Eilat (Gulf of Aquaba, Red Sea). Mar Biol. 19: 183-196

Francis, L. (1973). Intraspecific aggression and its effect on the distribution of Anthopleura elegantissima and some related sea anemones. Biol. Bull mar biol. Lab., Woods Hole 144: 73-92

Francis, L. (1976). Social organisation within clones of the sea anemone Anthopleura elegantissima. Biol. Bull. mar. biol. Lab., Woods Hole 150: 361-376

Franzisket, L. (1970). The atrophy of hermatypic reef corals maintained in darkness and their subsequent regeneration in light. Int. Revue ges. Hydrobiol. 55: 1-12 
Frydl. P. (1979). The effect of parrotfish (Scaridae) on coral in Barbados, W. I. Int. Revue ges. Hydrobiol. 64: 737-748

Geister, J. (1977). The influence of wave exposure on the ecological zonation of Caribbean coral reefs. Proc. 3rd Int Symp. Coral Reefs, Miami 1: 23-29

Gilmore, M. D., Hall, B. R. (1976). Life history, growth habits, and constructional roles of Acropora cervicornis in the patch reef environment. J. sed. Petrol. 46: 519--522

Ginsburg, R. N., James, N. P. (1973). British Honduras by submarine. Geotimes 18: 23-24

Ginsburg, R. N., Schroeder, J. H. (1973). Growth and submarine fossilization of algal cup reefs, Bermuda. Sedimentology 26: 575-614

Gladfelter, E. H., Monahan, R. K., Gladfelter, W. B. (1978). Growth rates of five reef-building corals in the northeastern Caribbean. Bull. mar. Sci. 28: 728-734

Glynn, P. W. (1973a). Aspects of the ecology of coral reefs in the western Atlantic region. In: Jones, O. A., Endean, R. (eds.) Biology and geology of coral reefs, Vol. 2. Academic Press, London, pp. 271-324

Glynn, P. W. (1973b). Ecology of a Caribbean coral reef. The Porites reef-flat biotope: Part I. Meteorology and hydrography. Mar. Biol. 20: 297-318

Glynn, P. W. (1973c). Ecology of a Caribbean coral reef. The Porites reef-flat biotope. Part II. Plankton community with evidence for depletion. Mar. Biol. 22: 1-21

Glynn, P. W (1973d). Acanthaster. effect on coral reef growth in Panama. Science, N. Y 180: 504-506

Glynn, P. W. (1974a). Rolling stones among the scleractinia: mobile coralliths in the Gulf of Panama. Proc. 2nd Int. Symp. Coral Reefs, Brisbane 2: 183-198

Glynn, P. W. (1974b). The impact of Acanthaster on corals and coral reefs in the eastern Pacific. Environ. Conserv. 1: 295-304

Glynn, P. W. (1976). Some physical and biological determinants of coral community structure in the Eastern Pacific. Ecol. Monogr. 46: 431-456

Glynn, P. W. (1977). Coral growth in upwelling and nonupwelling areas off the Pacific coast of Panama. J. mar. Res. 35: $567-585$

Glynn, P. W (1980). Defense by symbiotic crustacea of host corals elicited by chemical cues from predator. Oecologia (Berl.) 47: 287-290

Glynn, P. W., Stewart, R. H. (1973). Distribution of coral reefs in the Pearl Islands (Gulf of Panama) in relation to thermal conditions. Liminol. Oceanogr. 18: 367-379

Glynn, P. W., Stewart, R. H., McCosker, J. E. (1972). Pacific coral reefs of Panama: structure, distribution and predators. Geol. Rdsch. 61: 483-519

Glynn, P. W., Wellington, G. M., Birkeland, C. (1979). Coral reef growth in the Galapagos: limitation by sea urchins. Science, N. Y. 203: 47-49

Goodwin, M. H., Cole, M. J. C., Stewart, W. E., Zimmerman, B. L. (1976). Species density and associations in Caribbean reef corals. J. exp. mar. Biol. Ecol. 24: 19-31

Goreau, T. F. (1959a). The ecology of Jamaican coral reefs. I. Species composition and zonation. Ecology 40:67-90

Goreau, T. F. (1959b). The physiology of skeleton formation in corals. I. A method for measuring the rate of calcium deposition by corals under different conditions. Biol. Bull. mar. biol. Lab., Woods Hole 116: 59-75

Goreau, T. F. (1961a). Problems of growth and calcium deposition in reef corals. Endeavour 20: 32-39

Goreau, T F. (1961b). On the relation of calcification to primary productivity in reef building organisms. In: Lenhoff, H. M., Loomis, W. F. (eds.) The biology of Hydra and some other coelenterates. University Miami Press Florida, pp. 269-285

Goreau, T. F. (1963). Calcium carbonate deposition by coralline algae and corals in relation to their roles as reef builders. Ann. N. Y Acad. Sci. 109: 127-167

Goreau, T. F. (1969). Post Pleistocene urban renewal in coral reefs. Micronesica 5: 323-326

Goreau, T F., Burke, K. (1966). Pleistocene and Holocene geology of the island shelf near Kingston, Jamaica. Mar Geol. 4: 207-225

Goreau, T. F., Goreau, N. I. (1959). The physiology of skeleton formation in corals. II. Calcium deposition by hermatypic corals under various conditions in the reef. Biol. Bull. mar. biol. Lab., Woods Hole 117: 239-250

Goreau, T F., Goreau, N. I. (1960a). The physiology of skeleton formation in corals. III. Calcification rate as a function of colony weight and total nitrogen content in the reef coral Manicina areolata (Linnaeus). Biol. Bull. mar. biol. Lab., Woods Hole 118: 419-429

Goreau, T. F., Goreau, N. I. (1960b). The physiology of skeleton formation in corals. IV. On isotopic equilibrium exchanges of calcium between corallum and environment in living and dead reef-building corals. Biol. Bull. mar. biol. Lab., Woods Hole 119: 416-427

Goreau, T. F., Goreau, N. I. (1973). Coral reef project - Papers in memory of Dr Thomas F. Goreau. 17. The ecology of Jamaican coral reefs. II. Geomorphology, zonation, and sedimentary phases. Bull. mar. Sci. 23: 399-464

Goreau, T F., Goreau, N. I., Goreau, T. J. (1979). Corals and coral reefs. Scient. Am. 241: 110-120

Goreau, T. F., Goreau, N. I., Yonge, C. M. (1971). Reef corals: autotrophs or heterotrophs? Biol. Bull. mar. biol. Lab., Woods Hole 141: 247-260

Goreau, T. F., Graham, E. A. (1967). A new species of Halimeda from Jamaica. Bull. mar. Sci. 17: 432-441

Goreau, T. F., Wells, J. W. (1967). The shallow-water Scleractinia of Jamaica: revised list of species and their vertical distribution range. Bull. mar Sci. 17: 442-453

Goreau, T. F., Yonge, C. M. (1968). Coral community on muddy sand. Nature, Lond. 217: 421-423

Goren, M. (1979). Succession of benthic community on artificial substratum at Eilat (Red. Sea). J. exp. mar. Biol. Ecol. 38: $19-40$

Graus, R. R., Chamberlain, J. A., Boker, A. M. (1977). Structural modification of corals in relation to waves and currents. In: Frost, S. H., Weiss, M. P., Saunders, J. B. (eds.) Reefs and related carbonates - ecology and sedimentology. Am. Ass. Petr Geol., Tulsa, Oklahoma, pp. 135-153

Graus, R. R., Macintyre, I. G. (1976). Light control of growth form in colonial corals - computer simulation. Science, N. Y. 193: 895-897

Grigg, R. W., Maragos, J. E. (1974). Recolonization of hermatypic corals on submerged lava flows in Hawaii. Ecology 55: 387-395

Halldal, P. (1968). Photosynthetic capacities and photosynthetic action spectra of endozoic algae of the massive coral Favia. Biol. Bull. mar. biol. Lab., Woods Hole 134: 411-424

Harrigan, J. (1972). The planula larva of Pocillopora damicornis; lunar periodicity of swarming and substratum selection behavior. Ph. D. thesis. University Hawaii, Honolulu

Hartman, W. D. (1973). Beneath Caribbean reefs. Discovery 9: $13-26$

Highsmith, R. C. (1980a). Passive colonisation and asexual colony multiplication in the massive coral Porites lutea Milne Edwards and Haime. J. exp. mar. Biol. Ecol. 47 : $55-67$

Highsmith, R. C. (1980b). Burrowing by the bivalve mollusc 
Lithophaga curta in the living reef coral Montipora berryj and a hypothesis of reciprocal larval recruitment. Mar. Biol. 56: 155-162

Highsmith, R. C., Riggs, A. C., D'Antonio, C. M. (1980), Survival of hurricane-generated coral fragments and a disturbance model of reef calcification/growth rates Oecologia (Berl.) 46: 322-329

Hildemann, W. H., Raison, R. L., Cheung, G., Hull, C. J., Akaka, L., Okamoto, J. (1977a). Immunological specificity and memory in a scleractinian coral. Nature, Lond. 270 $219-223$

Hildemann, W H., Raison, R. L., Hull, C. J., Akaka, L., Okumoto, J., Cheung, G. $(1977 \mathrm{~b})$. Tissue transplantation immunity in corals. Proc. 3rd Int. Symp. Coral Reefs, Miami 1: 537-543

Hopkins, T. S., Blizzard, R., Brawley, S. A., Earle, S. A., Grimm, D. E., Gilbert, D. K., Johnson, P. G., Livingston, E. H., Lutz, C. H. (1977). A preliminary characterisation of the biotic components of the composite strip transects on the Florida Middlegrounds, Northeastern gulf of Mexico. Proc. 3rd Int. Symp. Coral Reefs, Miami 1: 31-37

Hubbard, J. A. E. B. (1972). Diaseris distorta, an acrobatic coral. Nature, Lond. 236: 457-459

Hubbard, J. A. E. B. (1974). Scleractinian coral behavior in calibrated current experiment: an index to their distribution patterns. Proc. 2nd Int. Symp. Coral, Reefs, Brisbane 2: $107-126$

Hubbard, J. A. E. B., Pocock, Y. P. (1972). Sediment rejection by Recent sclexactinian corals: a key to palaeo-environmental reconstruction. Geol. Rdsch. 61: 598-626

Hurlbert, S. H. (1971). The nonconcept of species diversity: a critique and alternative parameters. Ecology 52: 577-586

Jaap. W. C. (1979). Observations on zooxanthellae expulsion at Middle Sambo Reef, Florida Keys. Bull. mar Sci. 29: $414-422$

Jackson, J. B. C., Buss, L. W. (1975). Allelopathy and spatial competition among coral reef invertebrates. Proc. natr Acad. Sci. U.S.A. 72: 5160-5163

James, N. P. (1977). The deep and the past. Proc. 3rd Int Symp. coral reefs, Miami 2: XXV-XXVII

Jaques, T. G., Pilson, M. E. Q. (1980). Experimental ecology of the temperate scleractinian coral Astrangia danae. 1. Partition of respiration, photosynthesis and calcification between host and symbionts. Mar. Biol. 60: 167-178

Jaubert, J. (1977). Light, metabolism and growth forms of the hermatypic scleractinian coral Synaraea convexa Verill in the lagoon of Moorea (French Polynesia). Proc. 3rd Int. Symp. Coral Reefs, Miami 1: 483-488

Jaubert, J. M., Vasseur, P. (1974). Light measurements: duration aspect and the distribution of benthic organisms in an Indian Ocean coral reef, (Tuléar, Madagascar). Proc. 2nd Int Symp. Coral Reefs, Brisbane 2: 127-142

Jerlov, N. G. (1970). Light: General introduction. In: Kinne, O. (ed.) Marine ecology, Vol. 1, Environmental factors, Part 1 Wiley, London, pp. 95-102

Johannes, R. E. (1974). Sources of nutritional energy for reef corals. Proc. 2nd Int. Symp. Coral Reefs, Brisbane 1: 133-137

Johannes, R. E., Coles, S. L., Kuenzel, N. T. (1970). The role of zooplankton in the nutrition of some scleractinian corals. Limnol. Oceanogr 15: 579-586

Johannes, R. E., Tepley, L. (1974). Examination of feeding of the reef coral Porites lobata in situ using time lapse photography. Proc. 2nd Int. Symp. Coral Reefs, Brisbane 1: $127-131$

John, D. M., Pople, W. (1973). The fish grazing of rocky shore algae in the Gulf of Guinea. J. exp. mar Biol. Ecol. 11: $81-90$

Johnston, I. S. (1977). Aspects of the structure of a skeletal organic matrix and the process of skeletogenesis in the reef coral Pocillopora damicornis. Proc. 3rd Int. Symp. Coral Reefs, Miami 2: 447-453

Jokiel, P. L. (1978). Effects of water motion on reef corals. J. exp. mar. Biol. Ecol. 35: 87-97

Jokiel, P. L. (1980). Solar ultraviolet radiation and coral reef epifauna. Science, N. Y. 207: 1069-1071

Jokiel, P. L., Coles, S. L. (1974). Effects of heated effluent on hermatypic corals at Kahe Paint, Oahu. Pacif, Sci. 28: 1-18

Jokiel, P. L., Coles, S. L. (1977). Effects of temperature on the mortality and growth of Hawaiian reef corals. Mar Biol. 43: 201-208

Jokiel, P. L., Guinther, E. B. (1978). Effects of temperature on reproduction in the hermatypic coral Pocillopora damicornis. Bull. mar. Sci. 28: 786-789

Jokiel, P. L., Maragos, J. E. (1978). Reef corals of Canton Atoll: II. Local distribution. Atoll. Res. Bull. 221: 71-96

Kanwisher, J. W., Wainwright, S. A. (1967). Oxygen balance in some reef corals. Biol. Bull. mar. biol. Lab., Woods Hole 133: $378-390$

Kaufman, L. (1977). The three spot damselfish: effects on benthic biota of Caribbean coral reefs. Proc. 3rd Int. Symp. Coral Reefs, Miami 1: 559-564

Kawaguti, S. (1969). Effect of the green fluorescent pigment on the productivity of the reef corals. Micronesica 5: 313

Kevin, K. M., Hudson, R. C. L. (1979). The role of zooxanthellae in the hermatypic coral Plesiastrea urvillei (Milne Edwards and Haime) from cold waters. J. exp. mar. Biol. Ecol. 36: 157-170

Kinne, O. (1970). Temperature: Animals: Invertebrates. In: Kinne, O. (ed.) Marine ecology, Vol. 1, Environmental factors, Part 1. Wiley, London, pp. 407-514

Kinsman, D. J. J. (1964). Reef coral tolerance of high temperatures and salinities. Nature, Lond. 202: 1280-1282

Kohn, A. J. (1971). Inshore marine habitats of some continental islands in the Eastern Indian Ocean. Atoll. Res. Bull. 140: $1-29$

Kuhlmann, D. H. H. (1974). The coral reets of Cuba. Proc. 2nd Int. Symp. Coral Reefs, Brisbane 2: 69-83

Kuhlmann, D. H. H. (1975). Charakterisierung der Korallenriffe vor Veracruz/Mexiko. Int. Revue ges. Hydrobiol. 60: $495-521$

Ladd, H. S. (1977). Types of coral reefs and their distribution. In: Jones, O. A., Endean, R. (eds.) Biology and geology of coral reefs, Vol. 4. Academic Press, London, pp. 1-19

Land, L. S., Moore, C. H. (1977). Deep forereef and upper island slope, North Jamaica. In: Frost, S. H., Weiss, H. P., Saunders, J. B. (eds.) Reefs and related carbonates - ecology and sedimentology. Am. Ass. Petr. Geol. Tulsa, Oklahoma, pp. 53-65

Lang, J. C. (1971). Interspecific aggression by scleractinian corals. I. The rediscovery of Scolymia cubensis Milne Edwards \& Haime. Bull. mar Sci. 21: 952-959

Lang, J. C. (1973). Coral Reef Project - papers in memory of Dr. Thomas F. Goreau II. Interspecific aggression by scleractinian corals. 2. Why the race is not only to the swift. Bull mar. Sci. 23: 260-279

Lang, J. C. (1974). Biological zonation at the base of a reef. Am. Sci. 62: 272-281

Lang, J. C. (1980). Are the sweeper tentacles of Montastrea cavernosa polyfunctional organs? Abstract: Ass. Island Mar Labs., Discovery Bay, Jamaica

Lang, J. C., Hartman, W. D., Land, L. S. (1975). Sclerosponges: 
primary framework constructors on the Jamaican deep fore-reef. J. mar Res. 33: 223-231

Lasker, H. R. (1976). Intraspecific variability of zooplankton feeding in the hermatypic coral Montastrea cavernosa. In Mackie, G. O. (ed.) Coelenterate ecology and behaviour Plenum Press, New York, pp. 101-109

Lasker, H. R. (1977). Patterns of zooxanthellae distribution and polyp expansion in the reef coral Montastrea cavernosa. Proc. 3rd Int. Symp. Coral Reefs, Miami 1: 607-613

Lasker, H. R. (1979). Light dependent activity patterns among reef corals: Montastrea cavernosa. Biol. Bull. mar biol. Lab., Woods Hole 156: 196-211

Lasker, H. R. (1980). Sediment rejection by reef corals: the roles of behaviour and morphology in Montastrea cavernosa (Linnaeus). J. exp. mar. Biol. Ecol. 47: 77-87

Lehman, J. T., Porter, J. W. (1973). Chemical activation of feeding in the Caribbean reef-building coral Montastrea cavernosa. Biol. Bull. mar biol. Lab., Woods Hole 145: $140-149$

Lewis, J. B. (1964). Feeding and digestion in the tropical sea urchin Diadema antillarum Philippi. Can. J. Zool. 42: 549-557

Lewis, J. B. (1970). Spatial distribution and pattern of some Atlantic reef corals. Nature, Lond. 227: 1158-1159

Lewis, J. B. (1974a). The settlement behavior of planulae larvae of the hermatypic coral Favia fragum (Esper). J. exp. mar Biol. Ecol. 15: 165-172.

Lewis, J. B. (1974b). Settlement and growth factors influencing the contagious distribution of some Atlantic reef corals. Proc. 2nd Int. Symp. Coral Reefs, Brisbane 2: 201-206

Lewis, J. B. (1974c). The importance of light and food upon the early growth of the reef coral Favia fragum (Esper). J. exp. mar. Biol. Ecol. 15: 299-304

Lewis, J. B. (1975). Preliminary description of the coral reefs of the Tobago Cays, Grenadines, West Indies. Atoll. Res. Bull. 178: 1-14

Lewis, J. B. (1976). Experimental tests of suspension feeding in Atlantic reef corals. Mar. Biol. 36: 147-150

Lewis, J. B. (1977). Suspension feeding in Atlantic reef corals and the importance of suspended particulate matter as a food source. Proc. 3rd Int. Symp. Coral Reefs, Miami 1. $405-408$

Lewis, J. B., Price, W S. (1975). Feeding mechanisms and feeding strategies of Atlantic reef corals. J. Zool. Lond 176: $527-544$

Littler, M. M., Doty, M. S. (1975). Ecological components structuring the seaward edges of tropical Pacific reefs: the distribution, communities and productivity of Porolithon. J. Ecol. 63: 117-129

Loya, Y (1972). Community structure and species diversity of hermatypic corals at Eilat, Red Sea. Mar. Biol. 13: 100-123

Loya, Y. (1976a). Effects of water turbidity and sedimentation on the community structure of Puerto Rican corals. Bull. mar Sci. 26: 450-466

Loya, Y (1976b). Recolonisation of Red Sea corals affected by natural catastrophes and man-made perturbatons. Ecology 57: 278-289

Loya, Y (1976c). Settlement, mortality and recruitment of a Red Sea scleractinian coral population. In: Mackie, G. O. (ed.) Coelenterate ecology and behavior. Plenum Press, New York, pp. 89-100

Loya, Y. (1976d). The Red Sea coral Stylophora pistillata is an I-strategist. Nature, Lond. 259: 478-480

Loya, Y (1976e). Skeletal regeneration in a Red Sea scleractinian coral population. Nature, Lond. 261: 490-491

Loya, Y., Slobodkin, L. B. (1971). The coral reefs of Eilat (Gulf of Eilat, Red Sea). In: Stoddart, D. R., Yonge, C. M. (eds.) Regional variation in Indian Ocean coral reefs (Symp. zool. Soc. Lond. 28). Academic Press, London, pp. 117-139

Macintyre, I. G., Glynn, P. W. (1976). Evolution of modern Caribbean fringing reef, Galeta Point, Panama. Am. Ass Petrol. Geol. Bull. 60: 1054-1072

MacNeil, F. S. (1972). Physical and biological aspects of atolls in the northern Marshalls. Proc. Symp. Corals and Coral Reefs (1969). J. mar biol. Ass. India 1972: 507-567

Maragos, J. E. (1974a). Reef corals of Fanning Island. Pacif. Sci. 28: 247-255

Maragos, J. E. (1974b). Coral communities on a seaward reef slope, Fanning Island. Pacif. Sci. 28: 257-278

Mariscal, R. N., Bigger, C. H. (1977). Possible ecological significance of octocoral epithelical ultrastructure. Proc. 3rd Int. Symp. Coral Reefs, Miami 1: 127-133

Mariscal, R. N., Lenhoff, H. M. (1968). The chemical control of feeding behaviour in Cyphastrea ocellina and in some other Hawaiian corals. J. exp. Biol. 49: 689-699

Marshall, S. M., Orr, A. P. (1931). Sedimentation on Low Isles Reefs and its relation to coral growth. Scient. Rep. Gt Barrier Reef Exped. 3 (10): 273-312

Marshall, S. M., Stephenson, T A. (1933). The breeding of reef animals, Part I. The corals. Scient. Rep. Gt Barrier Reef Exped. 3: 219-245

Mergner, H. (1971). Structure, ecology and zonation of Red Sea reefs (in comparison with South Indian and Jamaican reefs). In: Stoddart, D. R., Yonge, C. M. (eds.) Regional variation in Indian Ocean coral reefs. (Symp. zool. Soc. Lond. 28). Academic Press, London, pp. 141-161

Mergner, $H$. (1972). The influence of several ecological factors on the hydroid growth of some Jamaican coral cays. Proc. Symp. Corals, Coral Reefs (1969). J. mar. biol. Ass. India 1972: 275-290

Mergner, H. (1977). Hydroids as indicator species for ecological parameters in Caribbean and Red Sea coral reefs. Proc. 3rd Int Symp. Coral Reefs, Miami 1: 119-125

Mergner, H., Scheer, G. (1974). The physiographic zonation and the ecological conditions of some south Indian and Ceylon coral reefs. Proc. 2nd Int. Symp. Coral Reefs, Brisbane 2: 3-30

Morelock, J., Schneidermann, N., Bryant, W R. (1977). Shelf reefs, southwestern Puerto Rico. In: Frost, S. H., Weiss, M. P., Saunders, J. B. (eds.) Reefs and related carbonatesecology and sedimentology. Am. Ass. Petr. Geol. Tulsa, Oklahoma, pp. 17-25

Moriarty, D. J. W. (1979). Biomass of suspended bacteria over coral reefs. Mar. Biol 53: 193-200

Munk, W. H., Sargent, M. C. (1948). Adjustment of Bikini Atoll to ocean waves. Trans. Am. geophys. Union 29 855-860

Murray, S. P., Roberts, H. H., Condon, D. M., Rudder, G. M (1977). Nearshore current fields around coral islands: control on sediment accumulation and reef growth. Proc. 3rd Int. Symp. Coral Reefs, Miami 2: 53-59

Muscatine, L. (1973). Nutrition of corals. In: Jones, O. A., Endean, R. (eds.) Biology and geology of coral reefs, Vol. 2. Academic Press, London, pp. 77-115

Muscatine, L., Porter, J. W. (1977). Reef corals: mutualistic symbioses adapted to nutrient poor environments. Bio Science 27: 454-460

Neudecker, S. (1977). Transplant experiments to test the effect of fish grazing on coral distribution. Proc. 3rd Int. Symp. Coral Reefs, Miami 1: 317-323

Neudecker, S. (1979). Effects of grazing and browsing fishes on the zonation of corals in Guam. Ecology 60: 666-672

Nishihira, M., Yamazato, K. (1974). Human interference with 
the coral reef community and Acanthaster infestation of Okinawa. Proc. 2nd Int. Symp. Coral Reefs, Brisbane 1: $577-590$

Odum, H. T., Odum, E. P. (1955). Trophic structure and productivity of a windward coral reef community on Eniwetok atoll. Ecol. Monogr. 25: 291-320

Ott, B. (1975). Community patterns on a submerged barrier reef at Barbados, West Indies. Int. Revue ges. Hydrobiol. 60: 719-736

Ott, B., Auclair, A. N. (1977). Cluster-analytic definition of species ecological groups for a submerged barrier reef in Barbados, West Indies. Int. Revue ges. Hydrobiol. 62: $41-51$

Ott, B., Lewis, J. B. (1972). The importance of the gastropod Coralliophila (Lamarck) and the polychaete Hermodice carunculata (Pallas) as coral reef predators. Can. J. Zool. 50: 1651-1656

Patton, W. K. (1976). Animal associates of living reef corals. In: Jones, O. A., Endean, R. (eds.) Biology and geology of coral reefs, Vol. 3. Academic Press, London, pp. 1-36

Pearse, V. B., Muscatine, L. (1971). Role of symbiotic algae (zooxanthallae) in coral calcification. Biol. Bull. mar. biol. Lab., Woods Hole 141: 350-363

Peyrot-Clausade, M. (1977). Settlement of an artificial biota by coral reef cryptofauna. Proc. 3rd Int. Symp. Coral Reefs, Miami 1: 101-104

Pichon, M. (1971). Comparative study of the main features of some coral reefs of Madagascar, La Reunion and Mauritius. In: Stoddart, D. R., Yonge, C. M. (eds.) Regional variation in Indian ocean coral reefs (Symp. zool. Soc Lond. 28). Academic Press, London, pp. 185-216

Pichon, M. (1972). Les peuplements a base de scleractiniaires dans les récifs corallians de la baie de Tuléar (Sud-ouest de Madagascar). Proc. Symp. Corals and Coral Reefs (1969). J. mar. biol. Ass. India 1972: 135-154

Pichon, M. (1974). Free living scleractinian coral communities in the coral reefs of Madagascar. Proc. 2nd Int. Symp. Coral Reefs, Brisbane 2: 173-181

Pichon, M. (1977). Physiography, morphology and ecology of the double barrier reef of North Bohol (Philippines). Proc. 3rd Int. Symp. Coral Reefs, Miami 2: 261-267

Pichon, M. (1978). Recherches sur les peuplements à dominance d'anthozoaires dans les récifs coralliens de Tuléar (Madagascar). Atoll. Res. Bull 222: pp. XXXV, 477

Pillai, C. S. G. (1969). The distribution of corals on a reef at Mandapam (Palk Bay) S. India. J. mar. Biol. Ass. India 11: $62-72$

Pillai, C. S. G. (1971). The distribution of shallow-water stony corals at Minicoy atoll in the Indian Ocean with a check list of species. Atoll. Res. Bull. 141: 1-12

Pillai, C. S. G. (1977). The structure, formation and species diversity of south Indian reefs. Proc. 3rd Int. Symp. Coral Reefs, Miami 1: 47-53

Porter, J. W. (1972a). Patterns of species diversity in Caribbean reef corals. Ecology 53: 745-748

Porter, J. W. (1972b). Predation by Acanthaster and its effect on coral species diversity. Am. Nat. 106: 487-492

Porter, J. W. (1972c). Ecology and species diversity of coral reefs on opposite sides of the Isthmus of Panama. Bull. Biol. Soc. Wash. 2: 89-116

Porter, J. W. (1973). Ecology and composition of deep reef communities off the Tongue of the Ocean. Bahama Islands. Discovery $9: 3-12$

Porter, J. W. (1974a). Zooplankton feeding by the Caribbean reef-building coral Montastrea cavernosa. Proc. 2nd Int. Symp. Coral Reefs, Brisbane 1: 111-125

Porter, J. W. (1974b). Community structure of coral reefs on opposite sides of the Isthmus of Panama. Science, N. Y. 186: $543-545$

Porter, J. W., (1976). Autotrophy, heterotrophy and resource partitioning in Caribbean reef building corals. Am. Nat. 110:731-742

Porter, J. W., Porter, K. G., Batac-Catalan, Z. (1977). Quantitative sampling of Indo-Pacific demersal reef plankton. Proc. 3rd Int. Symp. Coral Reefs, Miami 1: 105-112

Potts, D. C. (1976). Growth interactions among morphological variants of the coral Acropora palifera. In: Mackie, G. O. (ed.) Coelenterate ecology and behaviour. Plenum Press, New York, pp. 79-88

Potts, D. C. (1977). Suppression of coral populations by filamentous algae within damselfish territories. J. exp. mar. Biol. Ecol. 28: 207-216

Potts, D. C. (1978). Differentiation in coral populations. Atoll. Res. Bull. 220: 55-74

Purcell, J. E. (1977). Aggressive function and induced development of catch tentacles in the sea-anemone Met ridium senile (Coelenterata, Actiniaria). Biol. Bull. mar. biol. Lab., Woods Hole 153: 355-368

Randall, J. E. (1974). The effect of fishes on coral reefs. Proc. 2nd. Int. Symp. Coral Reefs, Brisbane 1: 159-166

Ray, K. J., Smith, S. V. (1971). Sedimentation and coral reef development in turbid water: Fanning Lagoon. Pacif. Sci. 25: $234-248$

Reed, J. K. (1980). Distribution and structure of deep water Oculina varicosa coral reefs of central eastern Florida. Bull. mar. Sci. 30: 667-677

Reese, E. S. (1977). Coevolution of corals and coral feeding fishes of the family Chaetodontidae. Proc. 3rd Int. Symp. Coral Reefs, Miami 1: 267-274

Rezak, R. (1977). West Flower Garden Bank, Gulf of Mexico. In: Frost, S. H., Weiss, M. P., Saunders, J. B. (eds.) Reefs and related carbonates - ecology and sedimentology. Am. Ass. Petr. Geol. Tulsa, Oklahoma, pp. 27-35

Richardson, C. A., Dustan, P., Lang, J. C. (1979). Maintenance of living space by sweeper tentacles of Montastrea cavernosa, a Caribbean reef coral. Mar. Biol. 55: 181-186

Riedl, R. (1971a). Water movement: General introduction. In: Kinne, O. (ed.) Marine ecology, Vol. I, Environmental factors, Part 2. Wiley, London, pp. 1085-1089

Riedl, R. (1971b). Water movement: Animals. In: Kinne, O. (ed.) Marine ecology, Vol. I, Environmental factors, Part 2. Wiley, London, pp. 1123-1156

Rinkevich, B., Loya, Y. (1979a). The reproduction of the Red Sea coral Stylophora pistillata. I. Gonads and planulae. Mar. Ecol. Prog. Ser. 1: 133-144

Rinkevich, B., Loya, Y. (1979b). The reproduction of the Red Sea coral Stylophora pistillata. II. Synchronization in breeding and seasonality of planulae shedding. Mar. Ecol. Prog. Ser. 1: 145-152

Roberts, H. H., (1972). Coral reefs of St. Lucia, West Indies Carib. J. Sci. 12: 179-190

Roberts, H. H., Murray, S. P., Sukayda, J. N. (1975). Physical processes in a fringing reef system. J. mar. Res. 33: 233-260

Robertson, R. (1970). Review of the predators and parasites of stony corals with special reference to symbiotic prosobranch gastropods. Pacif. Sci. 24: 43-54

Rogers, C. S. (1979). The effect of shading on coral reef structure and function. J. exp. mar. Biol. Ecol. 41; 269-288

Roos, P. J. (1967). Growth and occurrence of the reef coral Porites asteroides Lamarck in relation to submarine radiance distribution, Durkkerij, Elinkwijk, Utrecht

Rosen, B. R. (1971a). The distribution of reef coral genera in the Indian Ocean. In: Stoddart, D. R., Yonge, C. M. (eds.) 
Regional Variation in Indian Ocean coral reefs (Symp. zool. Soc. Lond. 28). Academic Press, London, pp. 263-299

Rosen, B. R. (1971b). Principal feature of reef coral ecology in shallow water environments of Mahe, Scychelles. In: Stoddart, D. R. Yonge, C. M. (eds.) Regional variation in Indian Ocean coral reefs (Symp. zool. Soc. Lond. 28). Academic Press, London, pp. 163-183

Rosen, B. R. (1975). The distribution of reef corals. Rep. Underwater Ass. 1: 1-16

Rosen, B. R. (1977). The depth distribution of Recent hermatypic corals and its palaeontological significance. Mem. bur Rech. Geol. miner. 89: 507-517

Rosen, B. R., Taylor, J. D. (1969). Reef coral from Aldabra: new mode of reproduction. Science, N. Y, 166: 119-121

Rutzler, K. (1972). Principles of sponge distribution in IndoPacific coral reefs: results of the Austrian Indo-West Pacific expedition 1959/60. Proc. Symp. Corals and Coral Reefs (1969). J. mar. biol. Ass. India 1972: 315-332

Salm, R. (1976). The structure and successional status of three coral reefs at Mauritius. Proc. R. Soc. Arts, Sci., Mauritius 3: $227-240$

Salvat, B., Ricard, M., Richard, G., Galzin, R., Taffort, J. L. (1977). Reef lagoon complex of Lakeba island (Lau group, Fiji) geomorphology, biotic associations and socio-ecology. Proc. 3rd Int. Symp. Coral Reefs, Miami 2: 297-303

Sammarco, P. W. (1980). Diadema and its relationship to coral spat mortality: grazing, competition and biological disturbance. J. exp. mar. Biol. Ecol. 45: 245-272

Sammarco, P. W., Levinton, J. S., Ogden, J. C. (1974). Grazing and control of coral reef community structure by Diadema antillarum Phillipi (Echinodermata Echinoidea): a preliminary study. J. mar. Res. 32: 47-53

Scatterday, J. W. (1974). Reefs and associated coral assemblages off Bonaire, Netherlands Antilles, and their bearing on Pleistocene and Recent reef models. Proc. 2nd Int. Symp. Coral Reefs, Brisbane 2: 85-106

Scatterday, J. W. (1977). Low water emergence of Caribbean reefs and effect of exposure on coral diversity - observations off Bonaire. Netherlands Antilles. In: Frost, S. H., Weiss, H. P., Saunders, J. B. (eds.) Reefs and related carbonates. Am. Ass. Petr. Geol. Tulsa, Oklahoma, pp. 155-169

Scheer, G. (1972). Investigations of coral reefs in the Maldive Islands with notes on lagoon patch reefs and the method of coral sociology. Proc. Symp. Corals and coral reefs (1969). J. mar. biol. Ass. India 1972: 87-120

Scheer, G. (1974). Investigation of coral reefs at Rasdu Atoll in the Maldives with the quadrat method according to phytosociology. Proc. 2nd Int. Symp. Coral Reefs, Brisbane 2. $655-670$

Scheer, G. (1978). Application of phytosociological methods. In: Stoddart, D. R., Johannes, R. E. (eds.) Coral reefs: research methods. UNESCO, Paris, pp. 175-196

Schroeder, J. H., Zankl, H. (1974). Dynamic reef formation: a sedimentological concept based on studies of recent Bermuda and Bahama reefs. Proc. 2nd Int. Symp. Coral Reefs, Brisbane 2: $413-428$

Schuhmacher, H. (1974). On the conditions accompanying the first settlement of corals on artificial reefs with special reference to the influence of grazing sea urchins (Eilat, Red Sea). Proc. 2nd Int. Symp. Coral Reefs, Brisbane 1: $257-267$

Schuhmacher, H. (1977a). Initial phases in reef development studied at artificial reef types off Eilat, (Red Sea). Helgoländer wiss. Meeresunters. 30: 400-411

Schuhmacher, H. (1977b). Ability in fungiid corals to over- come sedimentation. Proc. 3rd Int. Symp. Coral Reefs, Miami 1: 503-509

Schwenke, H. (1971). Water movement: Plants. In: Kinne, O (ed.) Marine ecology, Vol. I, Environmental factors, Part 2, Wiley, London, pp. 1091-1121

Scoffin, T P. (1972). Fossilization of Bermuda patch reefs. Science, N. Y 178: 1280-1282

Sebens, K. P. (1976). The ecology of Caribbean sea anemonies in Panama: utilization of space on a coral reef. In: Mackie, G. O. (ed.) Coelenterate ecology and behaviour. Plenum Press, New York and London, pp. 67-77

Sebens, K. P. (1977). Autotrophic and heterotrophic nutrition of coral reef zoonthids. Proc. 3rd Int. Symp. Coral Reefs, Miami 1: 397-404

Sheppard, C. R. C. (1979). Interspecific aggression between reef corals with reference to their distribution. Mar. Ecol. Prog. Ser. 1: 237-247

Sheppard, C. R. C. (1980a). Coral cover, zonation and diversity on reef slopes of Chagos atolls, and population structures of the major species. Mar. Ecol. Prog. Ser. 2: 193-205

Sheppard, C. R. C. (1980b). Coral fauna of Diego Garcia lagoon, following harbour construction. Mar. Pollut. Bull. 11: $227-230$

Sheppard, C. R. C. (1981a). Reef and soft-substrate coral fauna of Chagos, Indian Ocean. J. nat. Hist. 15: 607-621

Sheppard, C. R. C. (1981b). The groove and spur structures of Chagos atolls and their coral zonation. Estuar Coast. Shelf Sci. 12: 549-560

Sheppard, C. R. C. (1981c). Roles of interspecific and intraspecific competition in coral zonation. Prog. underwater Sci. 6: $57-60$

Sheppard, C. R. C. (1981d). Illumination and the coral community beneath Acropora tables. Mar Biol. 64: 53-58

Shinn, E. (1963). Spur and groove formation on the Florida reef tract. J. sed. Petrol. 33: 291-303

Shinn, E. (1976). Coral reef recovery in Florida and the Persian Gulf. Env. Geol. 1: 241-254

Slater, R. A., Phipps, C. V. G. (1977). A preliminary report on the coral reefs of Lord Howe Island and Elizabeth reef, Australia. Proc. 3rd Int. Symp. Coral Reefs, Miami 2: $313-318$

Smith, S. V., Ray, K. J., Schiesser, H. G., Shepherd, G. L., Chave, K. E. (1971). Flux of suspended calcium carbonate $\left(\mathrm{CaCO}_{3}\right)$, Fanning Island lagoon. Pacif. Sci. 25: 206-221

Sorokin, Y. I. (1973). On the feeding of some scleractinian corals with bacteria and dissolved organic matter. Limnol. Oceanogr. 18: 380-385

Squires, D. F., Keyes, I. W. (1967). The marine fauna of New Zealand: scleractinian corals. Mem. N. Z. oceanogr. Inst. 43: $1-29$

Stearn, C. W., Scoffin, T. P., Martindale, W. (1977). Calcium carbonate budget of a fringing reef on the west coast of Barbados. Bull. mar. Sci. 27: 479-510

Stimson, J. (1974). An analysis of the pattern of dispersion of the hermatypic coral Pocillopora meandrina var. nobilis Verrill. Ecology 55: 445-449

Stimson, J. S. (1976). Reproduction of some common Hawaiian reef corals. In: Mackie, G. O. (ed.) Coelenterate ecology and behaviour. Plenum Press, New York, pp. 271-279

Stimson, J. S. (1978). Mode and timing of reproduction in some common hermtypic corals of Hawaii and Enewetak. Mar. Biol. 48: 173-184

Stoddart, D. R. (1965). Resurvey of hurricane effects on the British Honduras reefs and cays. Nature, Lond. 207 : 589-592 
Stoddart, D. R. (1969). Ecology and morphology of recent coral reefs. Biol. Rev. 44: 433-498

Stoddart, D. R. (1972). Catastrophic damage to coral reef communities by earthquake. Nature, Lond. 239: 51-52

Stoddart, D. R. (1973). Coral reefs of the Indian Ocean. In: Jones, O. A., Endean, R. (eds.) Biology and geology of coral reefs. Vol. 1. Academic Press, London, pp. 51-91

Stoddart, D. R. (1974). Post-hurricane changes on the British Honduras reefs: resurvey of 1972. Proc. 2nd Int. Symp. Coral Reefs, Brisbane 2: 473-483

Stoddart, D. R. (1978). Descriptive reef terminology. In: Stoddart, D. R., Johannes, R. E. (eds.) Coral reefs: research methods. UNESCO, Paris, pp. 5-15

Stoddart, D. R., Johannes, R. E. (eds.) (1978). Coral reefs: research methods, UNESCO, Paris

Stoddart, D. R., Pillai, C. S. G. (1973). Coral reefs and reef corals in the Cook Islands, South Pacific. Oceanogr. S. Pacific 1972. New Zealand commission UNESCO, Wellington, pp. 475-483

Stoddart, D. R., Yonge, C. M. (eds.) (1971). Regional variation in Indian Ocean coral reefs (Symp. Zool. Soc. Lond. 28). Academic Press, London

Stoecker, D. (1980). Relationships between chemical defense and ecology in benthic ascidians. Mar. Ecol. Prog. Ser. 3 : $257-265$

Sukarno, S. (1972). Corals and coral reef study in Indonesia. Proc. Symp. Corals and Coral Reefs (1969). J. mar. biol. Ass. India 1972: 175-180

Svoboda, A. (1978). In situ monitoring of oxygen production and respiration in cnidaria with and without zooxanthelIae. In: McLuskie, D. S., Berry, A. J. (eds.) Physiology and behaviour of marine organisms. Proc. 12th Europ. Symp. Mar. Biol. Stirling, Scotland, Pergamon Press, Oxford, pp. $75-82$

Sweeney, B. M. (1976). Circadian rhythms in corals, particularly Fungiidae. Biol. Bull. mar. biol. Lab., Woods Hole 151: $236-246$

Taylor, D. L. (1974). Symbiotic marine algae: taxonomy and biological fitness. In: Vernberg, W. D. (ed.) Symbiosis in the sea. University South Carolina Press, Columbia, pp. 245-262

Tunnicliffe, V. (1981). Breakage and propagation of the stony coral Acropora cervicornis. Proc. natn. Acad. Sci. U.S.A.

Vacelet, J., Vasseur, P. (1977). Sponge distribution in coral reefs and related areas in the vicinity of Tuléar (Madagascar) Proc. 3rd Int Symp. Coral Reefs, Miami 1: 113-117

Van den Hoek, C., Cortel-Breeman, A. M., Wanders, J. B. W. (1975). Algal zonation in the fringing coral reef of Curaçao, Netherlands Antilles, in relation to zonation of corals and gorgonians. Aquat. Bot. 1: 269-308

Van den Hoek, C., Breeman, A. M., Bak, R. P. M., van Buurt, G. (1978). The distribution of algae, corals and gorgonians in relation to depth, light attenuation, water movement and grazing pressure in the fringing coral reef of Curaçao, Netherlands antilles. Aquat. Bot. 5: 1-46

Vasseur, P. (1974). The overhangs, tunnels and dark reef galleries of Tuléar (Madagascar) and their sessile invertebrate communities. Proc. 2nd Int. Symp. Coral Reefs, Brisbane 2: 143-159

Vasseur, P. (1977). Cryptic sessile communities in various coral formations on reef flats in the vicinity of Tulear (Madagascar). Proc. 3rd Int. Symp. Coral Reefs, Miami 1: 95-100

Veron, J. E. N. (1974). Southern geographic limits to the distribution of Great Barrier Reef hermatypic corals. Proc. 2nd Int. Symp. Coral Reefs, Brisbane 1: 465-473
Veron, J. E. N. (1978). Deltaic and dissected reefs of the far Northern Region. Phil. Trans. R. Soc. Lond. B 284: 23-37

Veron, J. E. N., Done, T. J. (1979). Corals and coral communities of Lord Howe Island. Aust. J. mar. Freshwat. Res. 30: 203-236

Veron, J. E. N., How, R. A., Done, T. J., Zell, L. D., Dodkin, M. J., O'Farrell, A. F. (1974). Corals of the Solitary Islands, central New South Wales. Aust. J. mar. Freshwat. Res. 25: 193-208.

Veron, J. E. N., Hudson, R. C. L. (1978). Ribbon reefs of the Northern Region. Phil. Trans. R. Soc. Lond. B 284: 3-21

Veron, J. E. N., Pichon, M. (1976). Scleractinia of Eastern Australia. 1. Families Thamnasteriidae, Astrocoeniidae, Pocilloporidae. Aust. Inst. Mar. Sci. Monogr. Ser 1: 1-86

Vine, P. J. (1974). Effects of algal grazing and aggressive behaviour of the fishes Pomacentrus lividus and Acanthurus sohal on coral reef ecology. Mar. Biol. 24: 131-136

Vosburgh, F. (1977). The response to drag of the reef coral Acropora reticulata Proc. 3rd. Int. Symp. Coral Reefs, Miami, 1: $477-482$

Wahle, C. M. (1980). Detection, pursuit and overgrowth of tropical gorgonions by Milleporid hydrocorals: Perseus and Medusa revisited. Science, N. Y. 209: 689-691

Wallace, C. C. (1978). The coral genus Acropora (Scleractinia: Astrocoeriina: Acroporidae) in the central and southern Great Barrier Reef Province. Mem. Qld Mus. 18: 273-319, Pls 43-103

Wallace, C., Dale, M. B. (1977). An information analysis approach to zonation patterns of the coral genus Acropora on outer reef buttresses. Atoll Res. Bull. 220: 95-110

Wallace, C., Lovell, E. R. (1977). Topography and coral distribution of Bushy and Redbill Islands and surrounding reef, Great Barrier Reef, Queensland. Atoll Res. Bull. 194: $1-22$

Wallace, R. J., Schafersman, S. D. (1977). Patch-reef ecology and sedimentology of Glovers Reef Atoll, Belize. In: Frost, S. H., Weiss, M. P., Saunders, J. B. (eds.) Reefs and related carbonates-ecology and sedimentology. Am. Ass. Petr. Geol. Tulsa, Oklahoma, pp. 37-52

Weber, J. N. (1973a). Reef corals and coral reefs in the vicinity of Port Moresby, south coast of Papua New Guinea. Pacif. Sci. 27: $377-390$

Weber, J. N. (1973b). Generic diversity of scleractinian reef corals in the Central Solomon Islands. Pacif. Sci. 27: 391-398

Wellington, G. M. (1980). Reversal of digestive interactions between Pacific reef corals - mediation by sweeper tentacles. Oecologia (Berl.) 47: 340-343

Wells, J. W (1954). Recent corals of the Marshall Islands, Bikini and nearby atolls, U. S. geol. surv. pap. 260: $385-486$

Wells, J. W. (1956). Scleractinia. In: Moore, R. C. (ed.) Treatise on invertebrate paleontology. University Kansas Press and Geol. Soc. Am., Part F, pp. 328-444

Wells, J. W (1957). Coral reefs. Mem. geol. Soc. Am. 67: 609-631

Wells, J. W. (1969). Aspects of Pacific coral reefs. Micronesica 5: $317-322$

Wells, J. W. (1973). Coral reef project - papers in memory of Dr. Thomas F. Goreau. 2. New and old scleractinian corals from Jamaica. Bull. mar Sci. 23: 16-58

Wethey, D. S., Porter, J. W (1976a). Habitat-related patterns of productivity of the foliaceous reef coral Pavona praetorta Dana. In: Mackie, G. O. (ed.) Coelenterate ecology and behaviour. Plenum Press, New York, pp. 59-66

Wethey, D. S., Porter, J. W. (1976b). Sun and shade differ- 
ences in productivity of reef corals. Nature, Lond. 262: $281-282$

Wiens, H. (1962). Atoll environment and ecology, Yale University Press, New Haven

Wijsman-Best, M. (1974). Habitat-induced modification of reef corals (Faviidae) and its consequences for taxonomy. Proc. 2nd Int. Symp. Coral Reefs, Brisbane 2: 217-238

Wilson, J. B. (1979). 'Patch' development of the deep-water coral Lophelia pertusa (L.) on Rockall Bank. J. mar. biol. Ass. U. K. 59: 165-177

Woodhead, P. M. J., Weber, J. N. (1969). Coral genera of New Caledonia. Mar. Biol. 4: 250-254

Wulff, J. L., Buss, L. W. (1979). Do sponges help hold coral reefs together? Nature, Lond, 281: 474-475
Yamaguchi, M. (1973). Early life histories of coral reef Asteroids, with special reference to Acanthaster planci L In: Jones, O. A., Endean, R. (eds.) Biology and geology of coral reefs, Vol. 2. Academic Press, London, pp. 369-387

Yamazato, K. (1972). Bathymetric distribution of corals in the Ryukyu Islands. Proc. Symp. Corals and Coral Reefs (1969). J. mar biol. Ass. India 1972: 121-133

Yonge, C. M. (1972). Aspects of productivity in coral reefs Proc. Int. Symp. Corals and Coral Reefs (1969). J. mar. biol Ass. India 1972: 1-12

Yonge, C. M. (1973). Coral reef project - Papers in memory of Dr. Thomas F. Goreau. 1. The nature of reef building (hermatypic) corals. Bull. mar. Sci. 23: 1-15

Topic and author of this review were suggested by Dr. J. S. Bunt; the review was accepted for printing on August 22,1981 